


\section{Capítulo 1 \\ A la escucha de Heidegger. \\ Aproximación a la no-ontología del comienzo que exige pensar el ser}

E 1 problema del ser surge en la filosofía y no deja de fluir como problema radical que aporta un fundamento al pensar, aun en épocas en que se consideró necio apelar a ello. Al contrario, en el caso de Heidegger, el sentido del ser es el problema primordial de la filosofía desde sus orígenes hasta la actualidad. He aquí el propósito de este apartado, partiendo de la condición que nos ofrece Rodolfo Kusch como filósofo que recibió una marcada influencia heideggeriana: comprender el acontecer ontológico como forma de ser propia de la filosofía, para cuyo cometido se auscultarán las obras de Heidegger, siguiendo un hilo cronológico, desde Heráclito y Parménides hasta Nietzsche, según el mismo Heidegger lo señaló.

Con dicho hilo cronológico no se quiere decir que se hará una presentación siguiendo la cronología de redacción heideggeriana, ni tampoco que se hará temporariamente, entendiendo esto desde el concepto de Temporalität, también elaborado por Heidegger. Ya en un curso temprano dictado en 1925-1926, en la Universidad de Marburgo, el filósofo señaló la diferencia entre lo temporal (Zeitlichkeit) y lo temporario (Temporalität): temporal "significa simplemente que algo transcurre, 
que sucede, que se realiza en el tiempo", mientras que temporario es aquello que le pertenece al tiempo, algo que está "caracterizado por medio del tiempo" (Heidegger, 2004, p. 163).

Lo que se realizará aquí será, entonces, mostrar cómo se desarrolla la ontología a través de la temporalidad (Zeitlichkeit) propia de la historia de la filosofía, lo que exigirá un rastreo de los escritos del filósofo alemán, para comprender el sentido de la ontología y algunos de sus conceptos afines, como simple punto de partida que se ofrece de marco teórico tanto para las investigaciones de Rodolfo Kusch como para esta que aquí se inicia.

Seguir ese hilo cronológico temporal tal vez responda a esa forma de la conciencia histórica con la que la actualidad asume el pasado, y en este caso concreto hace referencia al pasado y al presente de la ontología:

El modo como una época (la actualidad de cada momento) ve y aborda el pasado (el propio existir pasado o cualquier otro), lo guarda o renuncia a él, es la señal de cómo se relaciona el presente consigo mismo, de cómo en cuanto existir, en cuanto estar-aquí está su "aquí". (Heidegger, 2008a, p. 56. Énfasis añadido)

¿Cómo se ha comprendido y se comprende el problema del ser? Quién mejor que Heidegger para responder semejante interrogante. Seguir su desarrollo cronológico permitirá que el mismo problema se vaya mostrando. Y con Heidegger vamos a los inicios de la filosofía occidental para, así, comprender los orígenes del problema. No se trata de un simple volver hacia atrás la mirada, porque no se puede volver hacia atrás la historia, como el mismo Heidegger considera, pues ella apunta más bien al futuro: "Precisamente no queremos — ni podemos- volver hacia atrás la historia, sino que debemos pensar y actuar a partir de nuestro ser-necesario actual y eso significa ser-necesario futuro" (2008b, p. 104). Se busca, entonces, la comprensión del problema del ser como ontología en su acontecer, lo que exige una aclaración previa, la que el mismo Heidegger llamó "superación de la metafísica”. 
De forma explícita trató este asunto en un texto escrito en 1942, incluido junto con otros ensayos, en 1954, en la obra Conferencias y artículos (2001a). Allí se preguntaba qué significaba la superación de la metafísica y apuntaba que no se trataba de eliminarla, puesto que no podemos deshacernos de ella como de una opinión. "De ninguna manera se la puede dejar atrás como una doctrina en la que ya no se cree y que ya nadie defiende" (Heidegger, 2001a, p. 51), pues de todas maneras la metafísica, como manifestación del ente que se presenta ante un sujeto que lo toma como medida científica, no desaparecerá así como así. Sin embargo, más allá de la comprensión objetiva del ente en cuanto tal, se da la posibilidad de pensar el ser en la verdad que él mismo se devela, y esto ya no es algo metafísico:

La metafísica es fatalidad en el sentido estricto de esta palabra, en el único sentido en el que aquí nos referimos: en ella, como rasgo fundamental de la historia acontecida de la Europa occidental, deja las cosas del hombre suspendidas en medio del ente, sin que el ser del ente pueda jamás ser experienciado, interrogado y ensamblado en su verdad como el pliegue de ambos. (Heidegger, 2001a, p. 56)

En ese pliegue entre ente y ser, justamente, se abre la posibilidad de la superación de la metafísica, aunque esta todavía no se supere, según Heidegger, pues apenas es el comienzo de su fin. Y es un comienzo que emerge desde la metafísica misma, cuando empieza a dejarse atrás el olvido del ser. Claro que, en primera medida, se presenta un riesgo: con la terminación de la metafísica se nos impone de manera ineludible la técnica, que abraza la totalidad del ente, la naturaleza toda convertida en objeto. "El nombre 'la técnica' está entendido aquí de un modo tan esencial, que en su significado coincide con el rótulo: la Metafísica consumada" (Heidegger, 2001a, p. 58).

Si la metafísica se ha dedicado al ente y nada más, no puede devenir en otra cosa que en mera técnica, como al parecer está sucediendo. Técnica, trabajo masificado, consumo: ¿a esto queda reducida la metafísica en la modernidad debido al olvido del ser, a causa de haber 
abandonado el —estudio del— ser? "El consumo del ente, como tal y en su decurso, está determinado por el equipamiento en el sentido metafísico" (Heidegger, 2001a, p. 67), equipamiento para la guerra.

Aunque es verdad que trece años antes, en 1929, en su texto ya clásico ¿Qué es metafísica? (1979), no se expresó en tales términos y, por el contrario, de alguna manera sostuvo que el camino de la filosofía era el metafísico, en tanto que para el ser humano era necesario un salto que le diera "espacio a lo ente en su totalidad y, después, abandonarse a la nada" (Heidegger, 2007a, p. 108); en un texto posterior, de 1946, ya Heidegger afirmaba sin temor alguno que - si su tarea trata del ente- a la metafísica no le cabe pensar el ser: "La metafísica representa a lo ente en su ser y, por ende, también piensa al ser de lo ente. Pero no piensa el ser como tal, no piensa la diferencia entre ambos. La metafísica no pregunta por la verdad del ser mismo" (2007a, p. 266). De ello se comprende por qué, para Heidegger, era necesaria la superación de la metafísica, pues a esta se le había olvidado preguntarse por la verdad del ser, y se queda "más acá" en el mero ente.

Y puede que se le nombre como ser, pero en el fondo la metafísica trata solo del ente, inclusive cuando la filosofía se ha hecho crítica, como con Descartes y Kant, piensa desde y hacia el ente, cayendo en el olvido del ser, y eso es lo que hay que superar. ¿Con qué o cómo? En la "Carta sobre el Humanismo", Heidegger da a entender que con un pensar ontológico, al desarrollar la tarea del pensar: "El pensar está vinculado al advenimiento del ser, y en cuanto advenimiento está vinculado al ser" (Heidegger, 2007a, p. 296).

En otra carta, y esta aún más posterior, de 1955, publicada luego como "En torno a la cuestión del ser" (2007b), Heidegger afirma que "la superación de la metafísica es la superación del olvido del ser” (p. 337). Y aunque él mismo, en múltiples ocasiones, afirmó que el ser es ser de lo ente, también es cierto que fue el filósofo que con mayor clarividencia señaló la diferencia ontológica entre ser y ente, como se verá más adelante. Con esto se quiere destacar que es, pues, en la ontología, en la que deviene la superación de la metafísica, sobre el presupuesto por el que esta subsume lo ente mientras aquella subsume el ser. 
Dada esta aclaración, volvamos a lo que aquí nos interesa: cómo se ha comprendido el problema del ser a través de la historia de la filosofía, según los lineamientos que el mismo Heidegger nos ofrece en su obra escrita, ya que esta es la principal fuente que abre el horizonte ontológico de Rodolfo Kusch. No se ofrecerá aquí una periodización de la filosofía, ya que no fue la tarea del filósofo alemán, quien más bien estudió con juicio a los autores. Pero no se desaprovechará, tampoco, el valioso aporte que nos ofrece el documento Conceptos fundamentales de la filosofía antigua (2014a), el esbozo del curso del semestre de verano que ofreció Heidegger en 1926, en la Universidad de Marburgo, mientras empezaba a redactar Ser y tiempo. Este texto tiene un gran valor a la hora de comprender los conceptos fundamentales de la ontología griega, a partir del cual se identifican los autores con los cuales se inicia este recorrido.

\section{Heráclito}

Después de una amplia introducción a la filosofía antigua, guiándose por el primer libro de la llamada Metafísica de Aristóteles, y de una breve introducción a la primera sección de la segunda parte, Heidegger inicia con los pensadores que se dedicaron al problema del ser, y entre ellos considera primero a Heráclito. En la filosofía de la naturaleza, anterior al filósofo griego, su horizonte de comprensión no podía ser más que natural, físico $(\phi \cup \sigma \iota \varsigma)$, y por ello se concibió el primer principio o causa primera como algo intrínseco al ente mismo, a quien también es intrínseco, entre los griegos, el devenir y el movimiento.

Es en este contexto donde aparece Heráclito, quien sin intentar dar un salto a una causa primera diferente, según Heidegger, analiza a fondo cómo se muestra el ente en su totalidad, es decir, concibe al ente en su constitución fundamental de cambio (movimiento, devenir) y no en su simple apariencia estática, lo que resalta el filósofo alemán como un gran avance, puesto que esta nueva mirada rescata no solo las contradicciones "externas" entre lo que permanece y lo que cambia, sino también las “internas” de lo que está en movimiento, de lo que 
deviene siendo. Hermann Mörchen (2014), en los apuntes que tomó del curso en 1926, escribió:

El descubrimiento de la oposición significa la aprehensión de una nueva clase de diferencia y, por lo tanto, una penetración más profunda en la estructura del ser mismo. Todas las oposiciones tomadas en consideración se orientan por el Dasein humano como tal. Todo en el mundo es oposición. Y esto es más que decir: todo en el mundo cambia y se diferencia. (p. 264)

Si ha de concebirse un principio en Heráclito no estará, de ninguna manera, entonces, relacionado con el ente; al contrario, sería "lo que no puede ser visto ni aprehendido como ente, como algo que está ahí presente, sino como solo comprensible, diferente de todo ente" (Heidegger, 2014a, p. 79). En el texto del curso, Heidegger apenas señaló el fragmento 108 como dato; sin embargo, los apuntes de Mörchen evidencian que citó de manera textual a Heráclito: “De tantos discursos que he podido oír, ninguno reconoce que hay razón más allá de todas las cosas" ${ }^{1}$, para explicar con ello que la interpretación anterior del mundo, la de los físicos presocráticos, se quedó en el ente. En cambio, la comprensión de Heráclito resulta ser la primera aproximación trascendental al ser: "El ser se encuentra más allá de todo ente y no es más un ente. Primer avance hacia la idea de la trascendencia: el ser se encuentra más allá de todo ente” (Mörchen, 2014, p. 265), accesible en cuanto tal — como ser- solo para el $\varphi v \chi \eta$, 'sujeto' de comprensión ontológica.

Dos decenios después, Heidegger elaboró su hermenéutica textual del fragmento 5 de Heráclito, que fue publicado posteriormente en su colección de Conferencias y artículos. Trajo a colación la traducción que Snell hizo del mentado fragmento: "Si no me habéis oído a mí sino al sentido, / entonces es sabio decir en el mismo sentido: Uno es Todo”,

1 Los editores de la Gesamtausgabe señalan que los fragmentos de Heráclito son de la versión de Diels, confrontando la 4. ${ }^{a}$ y la 6. ${ }^{a}$ edición. Acá se cita la traducción hecha por Germán Jiménez al castellano, en 2014. 
de donde se dedujo que las dos acciones que nombran estos versos son oír y decir. Llamó la atención sobre el hecho de que en griego ambas se relacionan con el término $\Lambda$ oyos, lógos, por lo que propuso de inmediato ir tras del sentido original: $\lambda \varepsilon \gamma \varepsilon ı v$, légein.

¿Quién duda del significado de légein como 'decir', 'hablar', 'contar'? En lengua alemana también significa legen: 'poner abajo', 'poner delante'; así como en lengua latina deviene en legere: 'juntar', 'recoger'. Heidegger se pregunta cómo el sentido originario ('poner', legen) llega a significar 'decir' (en alemán lesen), y apunta taxativamente que "el leer que nosotros conocemos más, es decir, leer un escrito, sigue siendo, aunque ahora ha pasado a primer plano, una variedad del leer en el sentido de: llevar-a-que-(algo) esté-junto-extendido-delante" (2001a, p. 155), y lo relaciona con la recolección de espigas, la vendimia de las bayas, es decir, con la cosecha que se reúne y se pone "ahí", bajo techo, para preservarla, de donde se nota que el poner (como reunir) conlleva en esencia también el albergar (de algo que de antemano se elige) y, por consiguiente, también la elección. "Ahora bien, el verbo $\lambda \varepsilon \gamma \varepsilon ı v$, legen (poner), en su dejar-que-algo-esté puesto-delante-de-y-junto-a significa propiamente esto: que lo que está delante de y junto a nos importa y por esto nos concierne (va con nosotros)" (Heidegger, 2001a, p. 156), es decir, nos interesa (interés $=$ inter-esse $=$ entre-el-ser). Lo que se pone delante habiéndolo elegido y recogido nos hunde en el ser.

Es propio del légein el poner-delante-junto-cobijado. ¿Cuál es ese cobijo, según Heidegger? “Al $\lambda \varepsilon \gamma \varepsilon ı$, en su dejar-puesto-junto-delante, le importa este estado de albergamiento de lo que está puesto delante en lo desocultado [...] la presencia de lo puesto delante" (Heidegger, 2001, p. 156). La esencia del légein no es, entonces, hablar en cuanto decir y nada más; su tarea radica en poner delante lo que se devela (de lo elegido en la recolección), dentro de lo cual cabe el decir en cuanto una manera de desocultamiento. Y lo que se devela, hace presencia, se pone de presente: presencia de lo presente, ser del ente.

$\Lambda \varepsilon \gamma \varepsilon i v$, 'decir', entonces, no es meramente hablar, pronunciar palabras. Es este légein el que pone-delante el ser del ente. Y pone delante este ser del ente, justo, relacionándolo, pero así, de esta manera como Heidegger lo ha explicado a partir del fragmento 5 de Heráclito. Ahora bien, en este contexto, surge otra pregunta: ¿qué es el oír entonces? Así 
las cosas, oír no se reduce a la percepción de sonidos, sino a eso que comprendemos cuando le damos un profundo sentido al escuchar: es poner delante lo que estaba oculto y develarlo; cuando se sabe escuchar deviene algo así como una revelación. Develar, diría Heidegger, o en sus palabras: desocultamiento. Es así como llega a su concepción del lenguaje como morada del ser:

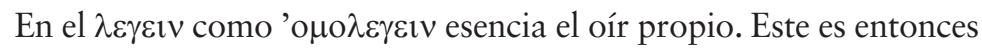
un $\lambda \varepsilon \gamma \varepsilon i v$ que deja estar-delante lo que ya está puesto-delante-junto, y lo está desde un poner que, en su estar extendido, concierne a todo lo que desde sí está puesto-delante-junto. Este poner especial

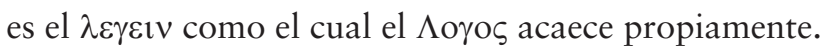

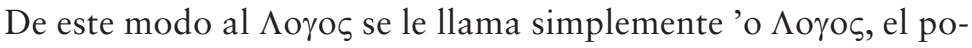
ner: el puro dejar-estar-delante-junto de lo que desde sí está de-

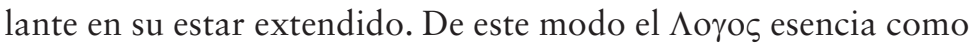

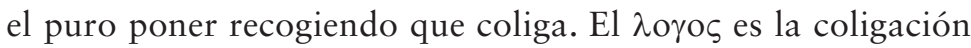
originaria de la recolección inicial desde la posada inicial. 'O

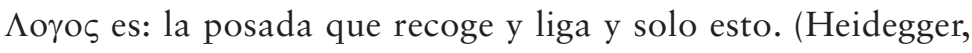
2001a, p. 159)

Este sentido del légein lo recoge Heidegger del mismo 'decir' de Heráclito. Como se ve en el texto griego, el verso citado inicia con un categórico no: ouk, [si] no me oyen a mí simplemente, [cuando] no me oyen simplemente a mí, sino que saben poner-se delante de lo develado, [entonces] lo sabio, lo [bien dis]puesto acaece en cuanto Uno es Todo.

Así, la traducción del fragmento heraclíteo ha ganado un sentido mucho más profundo que el anunciado al comenzar esta reflexión. Y Heidegger siguió aun profundizando más. Él comenta que las inter-

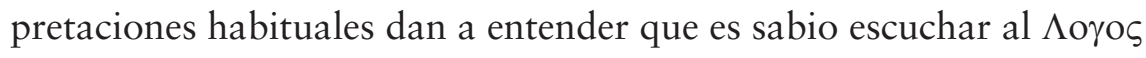
y repetir lo que este dice: todo es uno. Pero ya se aclaró que no es solo que el lógos diga algo (para repetirlo), sino que es el lógos el que se devela mostrándose (en lo que tenía de oculto), es decir que (lo que dice el lógos) lo que pone delante develando(se) el lógos, ¡esa es su esencia! El lógos, pone delante (de sí) todo lo que es: todo-uno. 
Todo-uno es como se presenta el lógos, como se devela, como deja de estar oculto. Su desocultamiento es la unidad del todo. Pero no una unidad ya dada como totalidad (terminada), sino en-desocultamiento, en devenir, a fin de cuentas: el lógos es justo ese devenir en que acaece todo lo que se devela (todo lo que es), pero dicho desocultamiento es, como se sabe, $\mathrm{A} \lambda \eta \theta \varepsilon 1 \alpha$, aléteia, verdad. Lo develado es la verdad. La verdad es lo que se pone delante, presente: todo-uno, todo-unido, todo-lo-que-es. "En el pensar de Heráclito aparece el

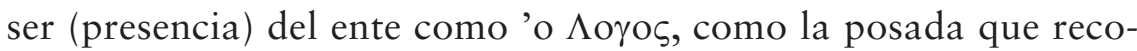
ge y liga. Pero este destello del ser permanece olvidado" (Heidegger, 2001a, p. 168). La historia de la filosofía da cuenta de ello: pensar el ser (ontología) ha caído en el olvido, la metafísica solamente se ha quedado en el estudio del ente. Y tal vez por esto mismo se ha etiquetado a Heráclito como "el oscuro", pues lo que pensó él fue lo profundo del ser:

El enigma, desde hace mucho tiempo, se nos ha dicho en la palabra 'ser'. Es por esto por lo que 'ser' sigue siendo solo la palabra provisional. Veamos la manera de que nuestro pensar no se limite a correr a ciegas detrás de ella. Consideremos primero que 'ser' significa inicialmente 'estar presente': morar y durar saliendo hacia delante, al estado de desocultamiento. (Heidegger, 2001a, p. 169)

La ontología no trata, pues, de la palabra ser. Una investigación ontológica no se queda en las palabras, ni siquiera en la palabra fundamental entre todas las que devienen en este estudio: ser. Por ahora, en Heráclito, ser es lo que deviene en el desocultamiento de lo que se pone delante, haciendo presencia (como ente), ligado en unidad, mostrándolo como un todo, pero sin confundir esa "totalidad-unida" con lo meramente ente-ahí-ante-los-ojos. Como bien lo señaló Heidegger, la filosofía de Heráclito es ontológica y no solo óntica, en la que se da un paso desde la búsqueda de las primeras causas y los principios de la naturaleza hacia la esencia de lo que hace presencia cuando se devela poniéndose presente, en ese devenir propio del desocultamiento. 


\section{Parménides}

Para Heidegger, el poema de Parménides se estructura en dos partes bien diferenciadas; una, dedicada a la verdad, y otra, dedicada a la opinión. En la primera parte, según los apuntes de Mörchen, el ser se comprende unido a la razón ya que, al ser común a todo ente, no se le puede asumir por partes, en pedazos, de tal manera que lo que se encuentra en él es unidad y totalidad: "Esta es la concepción griega del ser. Determinación del ente teniendo en vista el tiempo: único es solo lo que está presente, el presente mismo. Unidad, totalidad y presente son las tres dimensiones (del ser) en Parménides” (2014a, p. 269). Sin embargo, la dimensión temporal es bastante óntica acá: el tiempo se identificaba con aquello que permitía medirlo, con la esfera celeste, y de ahí que Parménides defina al ser de manera esférica (desde lo ente):

La comparación con una esfera bien redonda, que tiene igual fuerza en todas las partes a partir del centro. No es un accidente que la esfera sea presentada como símbolo del ser. En el análisis del ser se consideraba el tiempo, y la comprensión ingenua del tiempo se orienta por el curso del sol, por la esfera celeste. (Heidegger citado por Mörchen, 2014, p. 270)

Cuando uno se fija en las múltiples singularidades de este mundo, lo que sigue es el camino de la opinión. Solo en la reflexión, o mejor, en la meditación, deviene el ser en uno, en su unidad, y por ello es ahí donde encontramos la unidad entre pensar y ser, de la que habla Parménides. Desde esta se señalan las siguientes propiedades del ser: integrado, imperecedero, íntegro, único, inmóvil, sin fin, nunca ha sido, nunca será, es el ahora mismo, todo, uno, junto.

Heidegger señala que a partir de los versos 5 y 6 del fragmento 8 del poema se devela "una fuerza coercitiva sobre la relación efectiva entre ser y tiempo", que ha permanecido oscura desde los griegos hasta hoy (2014a, p. 89): el tiempo como ahora, ahora que (siempre) es, es (ser) que siempre es en el ahora: el ser como permanente presencia. 
Y de ahí que Parménides lo comprenda como siendo perfectamente siempre, sin oposición ni diferencia. En la medida en que lo analicemos en una determinada perspectiva, como un trozo o pedazo (del ser), de este se tendrá una determinada opinión: la temporalidad del ser, lo real; la intemporalidad del ser, lo ideal; la supratemporalidad del ser, la metafísica.

El mundo de la apariencia cambia, crece y desaparece, y los hombres se esfuerzan por fijar este cambio, dándole un nombre a cada uno de sus estadios. Pero los nombres no dicen nada, porque todas aquellas cosas a las que se refieren ya no son y no serán más. Por esto uno no puede fiarse de las palabras. Hay que volver a la aprehensión de las cosas mismas, y la única cosa que puede aprehenderse es lo que permanece, el ser. (Heidegger citado por Mörchen, 2014, p. 270)

Cuando en 1954 Heidegger publica su colección de Conferencias y artículos, ya citada, incluye también un texto sobre Parménides, centrado en los versos 34-41 del fragmento 8, que tratan de la identidad entre pensar y ser. Heidegger llama la atención en un detalle importante: en los citados versos, Parménides no usa el término 'ov (ente) ni tampoco ' $\varepsilon ı v \alpha \imath$ (ser), sino ' $\varepsilon o v$, que comprende más bien el pliegue entre ser y ente; es decir, lo que se despliega en ente del ser como de ser en el ente. Pero lo que hay de ser en el ente o cómo se da en ente el ser solo puede ser pensado... u olvidado. Si se toman por separado, ni el ser ni el ente implican el pensar, "pero, por el pliegue de ambos, por el ' $\varepsilon 0 v$, esencia el pensar" (Heidegger, 2001a, p. 179).

Así, el pensar es propio de ese pliegue que se da entre ser y ente; tampoco es propio únicamente del ser ni del ente (a no ser por traducciones deficientes del texto de Parménides, que traducen ' $E$ ov como ente o ser, de forma ingenua). Sin embargo, pensar tampoco es el pliegue mismo, aunque a él le pertenezca. "El pensar, en cierta perspectiva, está fuera de los límites del pliegue, hacia el que, correspondiendo a él y reclamado por él, está en camino" (Heidegger, 2001a, p. 185), pero en otra perspectiva, está dentro de los límites del pliegue: 
develándose, es decir, verdadeando, exteriorizando la presencia de lo presente en el pliegue.

Si a estas alturas se le preguntara al filósofo alemán qué es el ser, con certeza diría que el Ser es la verdad que deviene en la presencia de lo presente dado en el pliegue entre ser y ente. De alguna manera lo deja dicho así: "Si es que es legítimo hablar de la historia acontecida del ser, entonces debemos haber pensado antes que Ser quiere decir: presencia de lo presente: pliegue" (Heidegger, 2001a, p. 186). La presencia de lo presente dice (légein) la verdad que se extiende-delante en el pensar: se piensa lo que se expone delante, verdadeando la presencia de lo pres-ente, del ente. $\mathrm{Y}$ es en este sentido que se ha llegado a afirmar que pensar y ser son lo mismo, no tanto, según Heidegger, porque Parménides lo haya pensado, aunque sí lo describió así con el 'Eov; sino porque Heráclito lo pensó así, en el devenir que esencia la verdad del ente cuando hace presencia. En fin, "toda ontología que sigue a Parménides viene predeterminada por aquella decisión, que es la que le proporciona el hilo conductor" (Heidegger, 2008a, p. 117) a toda su apuesta.

Entonces, nos queda claro que el pensar es lo que acaece en el pliegue entre ente y ser, se da como desocultamiento (verdad) de lo pres-ente en la presencia, de donde se puede afirmar ya que acaece (acontece) la verdad-del-ser desde el ente que hace presencia. El ente solo, en-sí, no verdadea, como tampoco el ser en-sí, solo ahí; la verdad es el desocultamiento del pliegue que se abre entre ser y ente: (un) ente que está presente, ahí ante los ojos, y (el) ser que deviene verdadeando en la presencia que se despliega desde el ente. Ser-acaecimiento-verdadente en unidad dinámica, no se puede comprender lo uno sin lo otro ni todo como lo mismo, pues al fin y al cabo: ser y pensar son lo mismo, según el poema de Parménides.

\section{Otros presocráticos}

Antes de detenerse en Platón, en el curso de 1926, Heidegger analizó otros filósofos para desentrañar sus comprensiones ontológicas. Aunque Mörchen, en sus apuntes, revela las que debieron ser 
algunas explicaciones de Heidegger, en general, el filósofo alemán no dio cuenta de aportes destacados en este aspecto, llegando inclusive a afirmar que sus conceptos "no permiten avanzar en la comprensión del ser del ente" (2014a, p. 98), como en el caso particular de Zenón y Meliso.

A Empédocles, Anaxágoras y Leucipo los toma en conjunto, como "nuevos filósofos de la naturaleza", y considera que estos mantienen el concepto de ser ya ganado por Heráclito y Parménides, al mismo tiempo que se preguntan por el principio, pero dentro de un horizonte ontológico, principio de ese ente que se muestra desde su ser. "No el simple contrario del ser, la vana apariencia, sino el ente en su ser. No el ser en sí, en absoluto reposo, sino el ser del ente" (Heidegger, 2014a, p. 100), permanencia como fundamento subsistente del cambio. La lectura de estos pensadores exige, entonces, que no se interpreten solo a la luz de los primeros "filósofos físicos", ni tampoco a la luz de la filosofía moderna, como a veces se hace con los atomistas.

De igual manera, de forma rápida, echa un vistazo a la sofística, señalando en esta escuela a Protágoras, Gorgias, Hipias y Pródico, entre otros. De Sócrates, como es natural, dice que se dedicó a la comprensión de sí mismo (en Mörchen, 2014, p. 283), y por consiguiente su importancia radica en la comprensión del Dasein en general y de la virtud. Lo sintetiza con dos palabras: ser y sentido (2014, p. 114).

\section{Platón}

Según Heidegger, Platón pregunta "por la esencia del ente como ente en general, ipregunta por el ser!” (2014a, p. 121). Sin embargo, en el texto de 1926 que estamos siguiendo, no hay más que esbozos ligeros y poco argumentados.

Dejémonos guiar, entonces, por el curso que impartió en el invierno de 1933-1934, titulado "De la esencia de la verdad", y que desarrolló a partir de dos textos: La república y el Teeteto de Platón. Sin embargo, como lo que nos interesa es lo ontológico, no entraremos en detalles, por no venir al caso. De todas formas, no puede eludirse este curso 
que es uno de los más completos, entre los ofrecidos por Heidegger, en cuanto al desarrollo del problema de la verdad ${ }^{2}$.

La primera parte del curso se centra en la parábola de la caverna (Libro viI, pp. 514a-517a), cuyo objetivo es evidenciar lo verdadero, lo no oculto, ' $\alpha \lambda \eta \theta \varepsilon \varsigma$ (aletés). Ya es sabido cómo nuestro término verdad es la traducción indirecta del griego $\alpha \lambda \eta \theta \varepsilon i \alpha$ (aléteia), 'no ocultamiento', 'desocultamiento', y lo que se devela está más o menos develado (entre cosas y sombras, como en la caverna), por lo que se hace necesaria una liberación que lleve al afuera, ante la luz del sol donde es más seguro atenerse a lo real, a lo ente. Pero Platón asume este ente como sombra, por lo que cabe preguntarse, en este contexto, si lo ente es lo verdadero o si hay algo más allá de lo ente. A partir del texto platónico, Heidegger contesta: en Platón eso más allá de lo ente son las ideas, término este que de seguro se relaciona con $1 \delta \varepsilon \imath v$, 'ver':

¿Pero qué tipo de ver es ese en el que llegamos a ver la idea? Evidentemente, no puede ser el ver con nuestros ojos corporales, pues, al fin y al cabo, con estos vemos justamente lo ente, que, en la imagen, Platón designa como sombras. La idea debe ser otra cosa que lo ente. (Heidegger, 2007c, p. 55)

Y "lo otro que lo ente", en Heidegger, es el ser. "Los prisioneros en la caverna ven solo lo ente, sombras, y opinan que solo hay lo ente. No saben nada del ser, de entender el ser" (2007c, p. 59), por lo que se hizo necesario un ascenso para salir a la luz, donde hay claridad. En alemán 'claridad' es Helle, que viene del verbo hellen, que significa 'resonar', por lo cual se anota cómo originalmente dicha terminología hacía referencia al sonido, a la escucha, y cómo luego se relacionó

2 Lo que sea la verdad fue tema de reiterado interés por parte de Heidegger (al fin y al cabo él mismo comprende la identidad entre ser y verdad), lo trató en: el curso de invierno 1925-1926 (Gesamtausgabe, 21), la conferencia "De la esencia de la verdad" de 1930, pronunciada y publicada en diversas oportunidades; el curso iniciado el 27 de octubre de 1931 y finalizado el 26 de febrero de 1932; el curso de invierno 1933-1934 (Gesamtausgabe, 36-37); y en muchos otros pasajes cuando el problema del ser exigía tratar esta temática tan afín. 
con la claridad que ofrece la luz. De allí que la claridad resuene, se imponga, penetre y termine siendo aquello a través de lo cual vemos, gracias a su transparencia (también en alemán 'transparente', durchsichtig, significa 'lo que permite ver a través').

¿Y esto qué tiene que ver con las ideas de Platón?, pues que estas permiten saber lo que el ente es. La idea es la transparencia a través de la cual se ve lo ente, pero en la idea no está el ente sino su ser. "Solo donde se entiende el ser, el ser-qué de las cosas, la esencia, hay un tránsito para lo ente" (Heidegger, 2007c, p. 64). No se podría comprender lo ente (lo óntico) sin un entendimiento ontológico en el que se transparente, en el que él se devele. Vislumbrar ideas "significa entender el ser-qué y el ser-cómo, el ser de lo ente" (2007c, p. 66); el ser se devela (verdadea) de entre lo ente: $\tau$ o ov $\tau \omega \varsigma$ ov (to óntos ón). Por esto, para el filósofo alemán "la doctrina de las ideas es una ontología” (2014a, p. 123).

Heidegger se detiene a explicar el to óntos ón: cita en griego un apartado de La república (Libro vi, 490a-8 ss.) en donde Platón dice que quien en realidad quiere saber va directamente a lo ente, se dirige

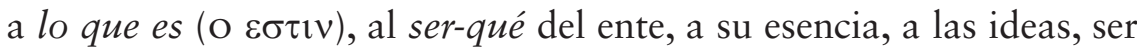

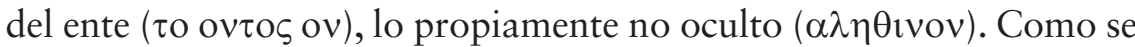
ve, este es uno de los textos más ricos, ontológicamente hablando. Al parecer, estamos acostumbrados a tomar de forma bastante superficial lo que son las ideas de Platón y a resaltar su contraste entre mundo físico perceptible y mundo de las ideas, sin más ni más. A veces se nos olvida que el horizonte de comprensión griego de Platón no es nuestro horizonte moderno poscartesiano de res extensa y res cogitans.

Es cierto que aun hoy día no se sabe qué sean esas ideas, pero no resulta bueno trasvasar de un horizonte de comprensión a otro de manera ingenua, ya que no puede ser tan simple. Por lo menos en el texto aludido, las ideas constituyen no otro mundo aparte, sino la esencia del ente, constituyen $\mathrm{el}$ ser de las cosas, iluminan lo que se devela (de entre) el ente:

En el origen del no-ocultamiento de las cosas, de lo ente, es decir, en su paso a través del ser, el engendrar vislumbrando que hemos caracterizado no está menos caracterizado que lo vislumbrado 
mismo en el mirar: las ideas. Que ellas constituyen conjuntamente el no-ocultamiento significa entonces que no son nada "en sí”, nunca son objetos. Es más, las ideas en tanto que lo avistado son solo (si es que podemos hablar así en general) en este mirar vislumbrando, tienen una referencia esencial con el engendrar vislumbrando. Por eso, las ideas no son objetos presentes, ocultos en alguna parte, que se pudieran hacer salir con un abracadabra. Pero tampoco son algo que los sujetos van llevando consigo, algo subjetivo en el sentido de que son hechas y pergeñadas por sujetos (hombres tal como los conocemos). No son ni cosas, objetivas, ni algo solo pensado, subjetivo. (Heidegger, 2007c, p. 77)

En Platón, pues, Heidegger encuentra un nexo esencial entre la verdad que se vislumbra en el desocultamiento del ente, y el ser de lo que es. A fin de cuentas es el hilo conductor de este curso de invierno y no otro: la verdad que se comprende en el ser del ente vislumbrada a la luz de su develarse, tarea que le corresponde al filósofo. Platón también anota en El sofista que es al filósofo a quien le importa vislumbrar el ser del ente (pp. 254-258), es el filósofo quien ve lo que se devela (lo que deja de estar encubierto) del (desde) ente.

Podría decirse, además, que se ve lo ente (y todo ser humano ve el ente) y se vislumbra el ser (y esta es la tarea del filósofo): vislumbrar, develar de entre lo ente el ser (to óntos ón), ese ser que verdadea el ente. También se sabe que, así como para los griegos la visión es el principal sentido y el ente visto depende de la luz, con el entendimiento se vislumbra el ser y lo vislumbrado depende del bien, $\alpha \gamma \alpha \theta$ ov (agatón). Es a este agatón que se debe el develamiento, el desocultamiento, en que verdadea el ser. "El bien es la capacitación, es la $\delta v v \alpha \mu \iota s$, el posibilitamiento del ser y del no-ocultamiento en su esencia" (Heidegger, 2007c, p. 111).

Así, en términos generales, y en lo que tiene que ver de forma explícita con el ser, finaliza la primera parte de este curso. A decir verdad, termina más bien con algo así como con una apología a la verdad, donde se nos insta a que nos corresponda el devenir de la verdad en nuestra historia, porque según Heidegger "el ser sucede como historia del hombre, como historia de un pueblo" (2007c, p. 141). Y es en 
este contexto donde surge otra pregunta: ¿cómo se dice la verdad?, ¿al decir lo verdadero también deviene la no verdad? Pero para ello ya se echa mano de otro texto: el Teeteto.

En la segunda parte del curso que estamos siguiendo, Heidegger se dedica a investigar con lujo de detalles aquel problema que ciertos filósofos griegos desecharon: la $\delta$ o $\alpha \alpha$ (dóxa), opinión. Tras la comprensión de la verdad, deviene la pregunta por la no verdad, y alrededor de esta emerge el problema de la opinión, que el filósofo alemán estudia de manera juiciosa como ningún otro.

En el diálogo se encuentran Sócrates, Teodoro y Teeteto conversando sobre la esencia del $\operatorname{saber}^{3}(\varepsilon \pi \imath \sigma \tau \eta \mu \eta)$, la cual pareciera ser la percepción, o por lo menos eso es lo que opina Teeteto. Normalmente nadie se detiene en la pregunta que le hace Sócrates a Teeteto, que del griego habría que traducirla como "¿cuál es tu opinión sobre el saber?, ¿qué opinas acerca de lo que es el saber?”, pues es a partir de la respuesta a esta, que se supone es una mera opinión, que se desenvuelve todo el diálogo.

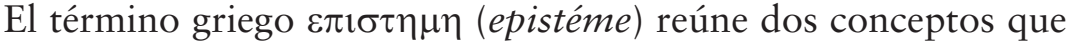
Heidegger señala con claridad: conocer como ver ( $1 \delta \varepsilon \imath$, según se comprendió en la primera parte del curso), y saber como entender-algo. $V e r$, en primera medida, es percibir, hacer presente, mantener presente, develar en presencia. "Conocer es tener presente lo compareciente en cuanto tal, tenerlo a disposición en su comparecencia, aun cuando haya de estar ausente" (2007c, p. 155).

Teeteto opina que el saber es $\alpha \imath \sigma \theta \eta \sigma ı \varsigma$ (aístesis), percepción, estar-percibido. Heidegger profundiza dicha opinión en cuatro pasos. Primer paso: se percibe lo ente; lo primero que se percibe, al mirar o al escuchar es que lo percibido es; lo que se percibe, se percibe porque algo está siendo ahí al oído o ante los ojos: es. Antes de saber qué es eso que tenemos ahí ante los ojos, por ejemplo, percibimos su presencia, percibimos que hay algo ahí, siendo. “Qué sea por su parte

3 Heidegger no usa este concepto en términos de saber-científico, ciencia, conocimiento científico, pues entre los griegos $\varepsilon \pi \imath \sigma \tau \eta \mu \eta$ significa 'entender algo dominándolo’, no necesariamente de forma científica (¡no con el concepto moderno de ciencia!). 
eso que se pone de relieve como 'excedente' (siendo, siendo distinto, siendo lo mismo), no lo sabemos" (Heidegger, 2007c, p. 179). Lo primero que se percibe es que (algo) está siendo ahí.

Segundo paso: la excedencia de lo percibido. El plus de lo que es: los detalles de lo que está siendo y que concretiza su estar siendo: todas sus determinaciones (en cuanto son y en cuanto no son), ser-lo-mismo o ser-distinto, de diversidad o de igualdad; es decir, todo aquello que determina al ente como ese que es, que está siendo, y que lo va asumiendo el alma como lo común a todo siendo.

Tercer paso: se refiere a cómo el alma puede llegar a percibir lo que es, las propiedades ontológicas de lo ente, y esto es posible, señala Heidegger, gracias a que la naturaleza del alma es aspiración-al-ser, tender a; no se podría comprender lo ente sin un horizonte de comprensión ontológico previo: el alma percibe lo ente desde una precomprensión del ser, y esa precomprensión, por llamarla así, es su tendencia, su aspiración a lo que es, de lo contrario sería imposible cualquiera de los pasos de la percepción.

Lo excedente que patentiza al ente en cuanto tal, según el cuarto y último paso que se dialoga en Teeteto, acaece por la corporalidad del ser humano con su naturaleza temporal; es decir, que en términos heideggerianos, también es ontológico. Se concluye así, en esta primera pesquisa, que la percepción (aístesis) va por otro camino que no es el de la episteme ni el del saber que se devela.

Antes de continuar, se hace necesario evidenciar cómo, en el transcurso de la mostración fenomenológica de la percepción, en la primera respuesta de Teeteto, Heidegger vislumbró aspectos ontológicos que enriquecen nuestra investigación. En la cotidianidad nos las habremos con entes, lo ente está ahí, ante nosotros, en todo lo que hacemos y por donde nos movamos. Obviamente es algo "normal" que no nos andemos preguntando por el ser de eso ente, no es que uno se la pase meditando acerca de cada uno de los entes con que se va topando día a día; pero sí es necesaria una comprensión previa del ser a la hora de vernos con lo ente: "Se necesita la más alta comprensión del ser, o sea, saber qué quiere decir propiamente ser, para poder abarcar con la vista y comprender todo el ente" (Heidegger, 2014a, p. 130). Y así, cuando se ha ganado un horizonte de comprensión ontológico, surge 
de manera más fácil la pregunta por el ser del ente. El problema es si sabemos qué sea el ser, “¿lo sabemos?”, pregunta Heidegger.

"El ser" es sustantivo del verbo ser, y su forma más conocida es la tercera persona del singular del tiempo presente: es, esto es una hoja, aquella es una flor. Dice Heidegger que en nuestro uso cotidiano del idioma siempre estamos expresándonos en términos de que esto es algo y eso es otra cosa; es decir que no podríamos expresarnos sin el uso del verbo ser. Pero si se nos pregunta qué es ser no sabemos, no tenemos claro el concepto de ser. Sin embargo, aunque no lo tengamos, no dejamos de expresarnos en esos términos, quizá porque "entender el ser está ya siempre ahí con nuestra existencia” (2007c, p. 199), podría decirse que es propio de nuestra humanidad.

El sentido de ser está arraigado en la humanidad y aunque la cultura de una época como la nuestra se incline más por lo ligero, lo inmediato y lo mediático, y sea indiferente a la búsqueda de un sentido profundo del ente y no tenga interés alguno por lo ontológico, aun así, siempre estaremos llamados a un nuevo despertar de nuestro sentido de ser. De igual manera, aunque en ámbitos académicos se crea que la cientificidad avanza por inmejorables caminos de objetividad en el estudio de la realidad, no estaremos más que equivocados en asegurar supuestos nada objetivos:

La tan celebrada "objetividad" de las ciencias sigue siendo un autoengaño mientras esta objetividad carezca de la recta relación fundamental con el objeto, que solo puede crecer en un arraigamiento de la existencia, y no puede conseguirse y ni siquiera protegerse con la puntualidad de los sabios. (Heidegger, 2007c, p. 200)

Lo objetivo se refiere a lo ente, y la percepción pertenece a eso óntico. El ser no se deja apañar con facilidad en la percepción óntica, pero siempre está referido a él. En el ser humano se da, siempre, un interés (inter-esse) por el ser, por encontrar en la percepción del ente algo más allá que hemos dado en llamar "su esencia”. Hay en el ser humano una aspiración al ser, es algo que se da, por decirlo de alguno forma, de manera "natural”. Así, en este contexto, Heidegger hace una 
primera aproximación conceptual al sentido del ser: "Es aquello que la mayoría de las veces y para todos siempre se ha activado ya y está ahí, pero no como una cosa ni como un objeto, sino como lo aspirado" (2007c, p. 207).

El ser se devela cuando el ser humano se aproxima a lo ente en la percepción, pero no porque dependa del ente y le pertenezca a él, sino porque esa aproximación perceptiva solo se da gracias a que en el ser humano ya está activada de antemano su aspiración al ser. Necesariamente, "no se trata de la referencia del ser con el pensamiento lógico ni con la formación lógica del pensamiento (formas del pensamiento y del juicio)" (2007c, p. 214), sino de algo más existencial, preobjetivo, no meramente óntico.

De alguna manera, el ser es posibilidad para el ente. Según Heidegger, no podría darse percepción (del ente) sin que se dé de antemano la aspiración al ser. "Solo porque el alma aspira al ser, puede a la luz de lo aspirado tener ante sí, es decir, percibir, es decir, tomar como verdadero, en cada caso esto o aquello dado como algo conseguido y tenido" (2007c, p. 219). El sentido de ser, pues, radica en el alma del ser humano, y solo desde ahí se proyecta la percepción del ente, por lo menos en esta primera aproximación al Teeteto de Platón, que finaliza con esta conclusión:

Aı $\sigma \eta \sigma \iota \varsigma \varepsilon \pi \imath \sigma \tau \eta \mu \eta$ ov $\tau \alpha u \tau o v$ (no son lo mismo) no tiene por

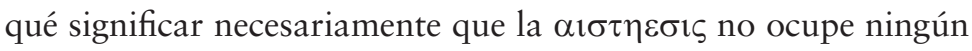
puesto ni desempeñe ninguna función en el saber sino que, por el contrario, puede dejar abierta la posibilidad de que, aunque la $\alpha \imath \tau \tau \eta \iota \varsigma$ forme parte del saber, e incluso necesariamente, sin embargo no lo constituye por sí misma ni en primera instancia. (Heidegger, 2007c, p. 233)

Hasta aquí se ha logrado discernir, entonces, que, tras comprender la esencia de la verdad, a partir del texto de La república de Platón, se conceptualizó el desocultamiento, no ocultamiento y desencubrimiento, y con la primera parte del Teeteto, como acabamos de ver, se mostró la aspiración al ser. Ambos, de todas maneras, son fenómenos arraigados 
en la existencia del ser humano, es decir, enraizados de manera existencial, a partir de lo cual Heidegger afirma que la pregunta por la verdad (y por el ser) es también la pregunta por el ser humano. Sin embargo, aún más allá de cualquier sesgo antropológico, se encuentra una base ontológica, desde la que se abre el horizonte de comprensión para, en este caso, entender la percepción y el saber: "La pregunta por la esencia del saber y su verdad es una pregunta por la esencia del ser" (Heidegger, 2007c, p. 238). Es decir: la pregunta por el saber (por la verdad) es, en el fondo, la pregunta por el ser desde la condición del alma humana, a sabiendas de que tal alma es aspiración al ser, como ya quedó dicho.

"Este comportamiento del alma que tienes a la vista como aquello donde está el saber (posesión de la verdad), me parece que se llama

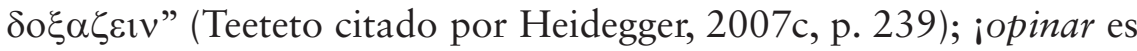
el comportamiento del alma en la aprehensión de la verdad! Entonces acá también es necesaria la pregunta por la opinión y hasta dónde esta tiene alguna relación con la verdad (del saber), porque la tradición ha señalado este concepto de forma despectiva, con el bien conocido dicho de "se opina cualquier cosa".

En griego, $\delta o \xi \varepsilon 1 v, \delta o \xi \varepsilon \omega$ significa me muestro (a mí mismo, a los demás), todo lo contrario a ocultarse. Al mostrarse se ofrece una apariencia, una imagen, por lo que este concepto conlleva el sentido de mostrarse de algún modo, de donde surge la idea de un manifestarse, de un aparecer, en el que se pone en duda si dicha apariencia es manifestación propia de sí o si es apariencia. Sin embargo, originalmente, esto no tuvo un viso negativo, puesto que lo que quería evidenciarse con dicho aparentar era una conducta: una forma de mostrarse, "desde aquel a quien algo se muestra expuesto, a quien le resulta así (en este caso es él mismo: se resulta a sí mismo así, se considera tal y cual" (Heidegger, 2007c, p. 242). Se considera de una forma o de otra, porque se ve (a sí mismo) de esa forma o de la otra, de allí que opinar también es un ver, una visión. La opinión, entonces, implica lo que se ve (se muestra) y, a la vez, cómo se ve.

Así pues, la palabra $\delta o \xi \alpha$, 'visión', tiene su significado desde dos direcciones opuestas: desde el objeto y desde el comportamiento. 
En una única palabra resuenan ambos significados, que algo ofrezca una imagen y el considerar que algo es así y así. Ahora bien, lo característico es que, para los griegos, en la $\delta o \xi \alpha$ ambos significados no son dos cosas yuxtapuestas sin conexión, sino que, en su peculiar pertinencia mutua, están referidas recíprocamente en lo más íntimo, y que justamente esta referencia en el asunto mentado con la palabra constituye lo esencial y lo estimulante de todo el problema. Si se entiende un significado, entonces también se actualiza el otro; $\delta$ o $\xi \alpha \zeta \varepsilon \imath v$ : tener una visión acerca de algo que se muestra así y así, que ofrece tal y cual visión, una apariencia. (Heidegger, 2007c, p. 243)

Apariencia tal que deja la duda sobre si está del lado de la verdad o del lado de la no verdad. Si está del lado de la no verdad sería una falsa opinión, algo así como una opinión invertida, una opinión de lo que no es. Pero ¿se puede conocer lo que no es?, ¿̇o se puede conocer solo lo que es? Heidegger explica cómo, en contra de lo que se piensa comúnmente, puede darse, de hecho, algo entre conocer lo que es y conocer lo que no es, algo así como el "entre" que debe darse entre ser y no ser, desde el cual se presenta la falsedad, "acometida contra el dominio del discurso cotidiano y contra el poder del sano entendimiento humano, que piensa en meras palabras y frases" (2007c, p. 260).

En cambio, es un hecho que así como algo se conoce o no se conoce, también algo se puede llegar a conocer cuando se está aprendiendo: en cierta manera no se conoce lo que apenas se está conociendo, pero también, ya se le conoce. Sí es posible, entonces, un término medio entre conocer y no conocer, entre verdad y no verdad, entre ser y no ser, y es ahí donde radica la importancia de la $\delta$ o $\xi \alpha$ y de lo que con ella se vislumbra. Detenerse, por ello, a pensar la opinión y a esclarecer su sentido no es cosa de segundo orden, ya que "puede decirse sin arrogancia que hasta el día de hoy se la ha malentendido por completo" (Heidegger, 2007c, p. 272).

La $\delta$ o $\xi \alpha$ permite comprender con claridad ontológica cómo el alma humana conoce las cosas en realidad. Pensar en algo no es más que traerlo al alma, ponerlo en presente, ya sea porque se le tiene ahí 
ante los ojos o porque hace presencia sin que lo tengamos "a ojos vistas". Es decir, dice Heidegger, no se trata ni de un recuerdo ni de una representación, en el pensar se mantiene "ante sí algo, un ente, y en concreto, también y justamente cuando este ente está ausente" (2007c, p. 277), a lo que se orienta el pensamiento es al ente mismo. Y presente o ausente es a él al que se dirige el alma, y llegando hasta él ¿nos topamos con él y lo integramos en su presencia a nosotros? No, con lo que nos topamos es con su ser, y es su ser el que es aprehendido por el alma: su ser, no es nuestra representación, ni nuestro recuerdo.

La impronta del ente en el alma es su ser, icon lo que nos las habremos es con el ser de las cosas cuando vamos a las cosas mismas! La realidad está ahí, ante nuestros ojos, pero el alma humana no carga con la realidad, sino con su ser, porque, como ya se había explicado antes, también es la naturaleza del alma aspirar a ese ser de lo ente. Así, pues, solo de forma ontológica mantenemos lo ente en presencia nuestra: el ser de las cosas, el ser de lo ente, de toda la realidad, es el modo como el alma humana mantiene presente el mundo con el que se topa y en el que se encuentra. Por esto Heidegger reitera que el alma "es en su esencia la relación del hombre con el ser de lo ente" (2007c, p. 282). ¿Cómo se percibe lo ente? Queda claro: estando presente y haciéndolo presente. "Con ello se abre una nueva perspectiva: el mismo ente puede estar al mismo tiempo en referencia con la $\alpha \iota \sigma \theta \eta \sigma \iota \varsigma$ y con la $\delta \imath \alpha v o r \alpha$, ambas pueden ir juntas de una forma nueva" (Heidegger, 2007c, p. 288), y esto es lo que sucede en el ejercicio de la opinión. Véase la estructura de la $\delta o \xi \alpha$ en palabras de Heidegger:

Primero, un contemplar la imagen que está presente de lo que viene al encuentro $[\ldots]$ y luego un "tomar por" que hace presente. Ya que ambos momentos, el estar presente y el hacer presente, forman parte de la esencia de toda $\delta o \xi \alpha$, ella tiene la doble posibilidad: en función de esta esencia, podemos hacer pie primero una vez en lo que se ofrece estando presente, y otra vez en el hacer presente. Por eso la visión $(\delta \circ \xi \alpha)$, según su esencia propia, puede tomarse ya de un modo, ya de otro. De este modo, toda $\delta o \xi \alpha$ 
es necesariamente equívoca: imagen como ofrecer, y visión como opinión. (2007c, p. 291)

Si se toman sus dos elementos constitutivos en unidad puede comprenderse la opinión $(\delta o \xi \alpha)$ como lo-que-se-ve considerado-como, es decir, un tanteo-de(l)-ser; pero si se toman, de acuerdo a su naturaleza misma, separados, es la misma opinión la que posibilita tanto la verdad como la no verdad. Es propio de esa doble posibilidad, de esa bifurcación, que uno pueda equivocarse (Heidegger, 2007c, pp. 294-297); es decir que, tras la verdad (desocultamiento) puede devenir la no verdad (y, así, ocultarse el ser de lo ente, ¡y hasta la pregunta misma!):

[...] de la posibilidad interna de la verdad, forma parte la no-verdad. Por consiguiente, la pregunta por el ser es completamente equívoca: por la más profunda verdad y al mismo tiempo siempre al borde y en la zona de la más profunda no-verdad. (Heidegger, 2007c, p. 301)

Así, una historia de la ontología podrá ir dando cuenta de cómo se ha asumido la pregunta por el ser y qué tanto nos hemos aproximado a su respuesta, o si como sentencia Heidegger, inos hemos olvidado del ser! Pero es que dicho olvido va ocurriendo, tal vez, por su misma naturaleza, ya que al fin de cuentas ser no es más que devenir y negación. Devenir es cambio, y en ese sentido, negación; el devenir niega, de todas maneras, lo ente, y con ello el ser. Con el devenir se percibe el no ser, pero esto ratifica el ser. Y acá el sentido de la negación viene a afirmar, es decir que el devenir ratifica al ser, porque "todo se mueve, el movimiento es el ser” (Heidegger, 2014a, p. 144).

Esta apuesta por la opinión como fuente de verdad y de no verdad resulta fundamental: no es solamente cierto que la opinión nos pueda llevar a equivocarnos, pues, de hecho, nos puede llevar a la no verdad. Es también cierto que la verdad deviene de la opinión, en el sentido en que Heidegger lo expuso, renovando el sentido original de $\delta o \xi \alpha$. "Ahora se la ve más positivamente, porque hay en ella algo que hace posible el saber" (2014a, pp. 150, 159-162), y ese "algo" es la 
verdad ${ }^{4}$. Pero con esto también se renueva el sentido de la negación: el no es algo así como el dínamo del devenir, es lo otro que dinamiza el devenir del ser; no es la diferencia total y, como absoluta de $l o$ que es, no es lo que "conduce a la nada, sino que hace ver" (2014a, p. 154), retrotrae a la verdad en la opinión, es lo otro que ratifica lo mismo (la identidad de lo que es).

\section{Aristóteles}

Como se sabe, Heidegger encontró en Aristóteles un pilar desde donde auscultó el problema del ser, empezando por el texto de Franz Brentano que leyó a muy temprana edad, cuando aún era estudiante de bachillerato, en 1907): Sobre los múltiples significados del ente en Aristóteles (2007), publicado por primera vez en 1862.

En este apartado se seguirá un orden cronológico de lo escrito por el filósofo alemán al respecto. Tenemos, primero, las Interpretaciones fenomenológicas sobre Aristóteles (2002), que datan de 1922; segundo, el curso que al final tituló Ontología. Hermenéutica de la facticidad (2008a), de 1923; tercero, Introducción a la investigación fenomenológica (2006a), de 1923-1924; cuarto, el texto que nos ha guiado hasta acá, Conceptos fundamentales de la filosofía antigua (2014a), de 1926; quinto, uno de los textos más rigurosos, el curso que dictó en 1927, mientras terminaba de escribir y se editaba Ser y tiempo. Los problemas fundamentales de la fenomenología (Sein und Zeit, 1963); sexto, Preguntas fundamentales de la filosofía (2008b), de 1937-1938; y séptimo, uno de los capítulos de Hitos, el que está dedicado al concepto de naturaleza en Aristóteles: "Hegel y los griegos" (2007e), que es de 1939.

4 No sé hasta dónde Heidegger mantuvo esta opinión, pero por lo menos en 1926, en el curso de Marburgo, lo tenía muy claro: las opiniones siempre tienden a la verdad, no pueden darse las opiniones falsas, porque al fin y al cabo se opina lo que es y no puede ser de otra manera; el mismo Mörchen (2014) lo evidencia en sus apuntes de clase, como puede verse en las páginas 304-305. Pero Heidegger, también es cierto, finaliza este estudio sobre Platón expresando que no ha llegado a conclusión alguna y que estos son solamente impulsos renovados. 
Para presentarse al concurso docente de la Universidad de Marburgo y ser nombrado profesor ordinario, Heidegger, en 1922, escribió un informe de unas sesenta páginas titulado Interpretaciones fenomenológicas sobre Aristóteles. Indicación de la situación hermenéutica (2002), también conocido como Informe Natorp, en el que dio cuenta del estado de sus investigaciones. El sesgo subjetivista hacia la fenomenología de Husserl es evidente, pero el interés por lo ontológico dejó sus huellas. Un interés que se da a partir de la comprensión de la vida humana, pero también en la pregunta por el ser, y la cual responde, en ese momento, en estos términos: "Ser significa ser-producido y, en cuanto producido, en cuanto que algo resulta significativo para el trato, también significa estar-disponible [...]" (Heidegger, 2002, p. 57).

El ente, entonces, en cuanto ovora (entendido en el sentido del griego temprano como conjunto de bienes patrimoniales, de bienes familiares, hacienda; lo que se tiene a la mano para vivir, lo que se produce para poder existir), se debe cuidar, custodiar, apropiarse de él. ¿De qué manera se le custodia? Según Heidegger hay cinco modos de tal cuidado ontológico, pero excluye dos: la conjetura y la opinión, porque llevan al engaño (ya sabemos que de 1922 a 1926 su posición al respecto dio un vuelco). Las cinco formas de "comprender" el ser serían: la producción $(\tau \varepsilon \chi \nu \eta)$, la discusión argumentativa ( $\varepsilon \pi 1 \sigma \tau \eta \mu \eta)$, la (diligente) solicitud ( $\phi \rho \circ \eta \eta \sigma \iota)$, la comprensión intuitiva ( $\sigma \circ \phi \imath \alpha)$ y el mero inteligir (vous).

En el ejercicio de la custodia del ente, este se devela, y es ahí donde aparece el problema de la verdad, no como adecuación (en Aristóteles no existe semejante concepto), sino como develamiento, desocultamiento, pero es el ente mismo el que se devela. En ese entonces, Heidegger no dio muestras de tener clara la diferencia ontológica que definió años después, y sus investigaciones en ese momento no van más allá de una "ontología del ente", y en concreto del ente-vital, sujeto de la vida (de la vida humana, del alma humana).

El problema de investigación, que se devela desde la obra misma de Aristóteles, lo expone Heidegger en estos términos:

¿Han incorporado los físicos antiguos el ente entendido como $\phi ı \imath \iota$ en el proyecto de la investigación, de tal manera que su 
carácter fenoménico decisivo - aquel que la investigación anterior ya siempre presupone de alguna manera en sus diferentes modalidades de discurso: a saber, el del movimiento- quede custodiado y explicitado originariamente? O, por el contrario: ¿acaso el modo como la investigación tradicional accede al ámbito del ser en cuestión no se mueve, de entrada, en "teorías" y tesis fundamentales que no solo se extraen del ámbito del ser, sino que directamente le cierran el paso? (2002, p. 78)

Porque para Aristóteles el presupuesto desde el que se parte en su Física es que hay entes en movimiento, pues la observación de la $\phi \imath \iota \varsigma$ es lo que se evidencia, cuestionando así los postulados de la escuela eleática, pero no sin valorar aportes tan valiosos como el de la unidad entre ser y pensamiento, que indica Parménides en su poema, donde se encuentra no solo la primera mirada ontológica, dice, sino a su vez la última. Sin embargo, más adelante, al analizar los capítulos 4 a 7 de la Física de Aristóteles, Heidegger evidencia que dichos "análisis ontológicos no solo no han sido todavía superados hasta la actualidad, sino que ni siquiera han sido comprendidos y valorados como tales" (2002, pp. 81-82).

Luego, al hablar sobre el texto Metafísica, declara cómo la problemática fundamental de la ontología "desemboca en la elabora-

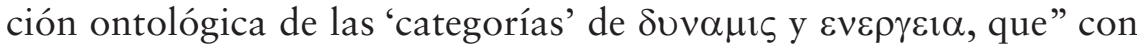
las categorías aristotélicas en sentido estricto "son constitutivas para el 'ser del ente"” (2002, p. 82). De allí se deduce que para 1922 ya Heidegger había vislumbrado el ser desde la concepción del movimiento, del acaecimiento, e iniciaba un camino que lo llevaría a una novedosa comprensión del problema del ser más allá de categorías "estáticas” y "abstractas", hacia un horizonte de comprensión del ser que parte de esa estancia, de esa hacienda concreta. En estos últimos conceptos es donde se producen entes necesarios para la existencia cotidiana, aunque, de manera ingenua, se les vean como meramente accidentales: los accidentes ofrecen un sentido propio del ser, pues Aristóteles "interpretó ontológicamente la accidentalidad" desde un sentido de ser que "tiene su origen en el mundo circundante" (Heidegger, 2002, p. 85), y que empieza a perder su verdadero 
sentido reduciéndose poco a poco a la existencia real y efectiva, apenas realidad, mera efectividad.

El último curso que dictó Heidegger en la Universidad de Friburgo, en 1923, antes de viajar a Marburgo, lo tituló Ontología. Hermenéutica de la facticidad. El texto que nos ha llegado parece más bien el esbozo de las lecciones, inclusive por la extensión, y de Aristóteles no hay más que breves referencias. Pero llama la atención porque allí se hacen algunos apuntes ya bastante claros respecto a la relación que Heidegger siempre encontró entre ontología y lenguaje (a diferencia de algunos “críticos”, que insisten en diferenciar dos etapas en la filosofía del pensador alemán, con las que ni él mismo estuvo de acuerdo).

Heidegger cita aquella parte del De anima ${ }^{5}$ que dice: "Lo ente en cuanto viviente necesita la lengua para saborear tanto como para conversar acerca del trato con las cosas; de ello, el saborear es un modo necesario del trato con las cosas”. Y de aquí parte para mostrar cómo en la conversación con alguien de algo se garantiza el ser de lo viviente, dicha conversación (el hablar coloquial de algo) es el modo fáctico de realización del lógos, en el que lo ente se hace accesible, se hace presente. Se observa, entonces, cómo, a partir de esa breve cita del estagirita, Heidegger señala varios aspectos que no son nada ortodoxos: primero, es desde el hablar coloquial, desde la conversación, y no desde el texto argumentativo o científico, donde se origina la accesibilidad del ser (esto no será sostenido en estos términos más adelante por el filósofo alemán, pero lo que se quiere resaltar acá es que no hay una actitud despectiva con respecto a la conversación coloquial, no hay esa pedantería académica con que algunos filósofos se consideran los dueños de la sabiduría y, según eso, solo ellos son los poseedores de la verdad); segundo, lo conversado son las cosas, el ente, desde el que se devela el ser, iy esta es la naturaleza del lógos: traer a su presencia lo que es, el ser de las cosas!

La función del habla es hacer accesible algo en cuanto estando aquí presente, mostrándose abiertamente. En cuanto tal, tiene el

5 Heidegger trae la cita en griego, tomada de De anima B, 8, 420b-18 ss. 



aquí a la vista, a disposición de lo que antes estaba oculto, encubierto). (Heidegger, 2008a, p. 29)

Como se ve, no son sino estos dos elementos los que extrae Heidegger de la referencia explícita a Aristóteles en dicho curso. Pero son dos elementos claves, que resultan fundamentales en la investigación que acá seguimos.

Heidegger también trata sobre Aristóteles en el primer curso ofrecido en la Universidad de Marburgo: Introducción a la investigación fenomenológica (2006a), en la primera parte. El apartado sobre la fenomenología es una apuesta de la filosofía del lenguaje que complementa y radicaliza lo que se señaló respecto a Platón. A propósito del De anima de Aristóteles, Heidegger considera que fenómeno no es más que un modo destacado de la presencia del ente, presencia que se muestra tanto en la claridad como en la oscuridad, porque según dice Aristóteles en Del alma (B7, 419a-1 ss.), no todo es visible a la luz, también se da lo visible en la oscuridad. Esta, la oscuridad, también — como la luz — deja ver, pues "el ser de la oscuridad consiste en ser claridad posible" (Heidegger, 2006a, p. 31).

El fenómeno es lo que se muestra a sí mismo en sí mismo para quien lo percibe, cuya percepción ( $\left.\alpha \_\sigma \xi \theta \eta \sigma \iota \varsigma\right)$ implica un elemento estructural vital en el hecho fenomenológico. Y este hecho - lo fenómeno- " "no es una categoría conceptual, sino un modo de ser" (Heidegger, 2006a, p. 33), modo de ser del ente:

6 Los conceptos que se hacen clásicos y tradicionales en la filosofía a veces recogen los vicios de una determinada cultura o de un determinado momento histórico que los asumió dentro de una concepción que sesgó su sentido y solamente dio claridad a una arista del mismo, opacando otros sentidos también propios de aquello que se quiere relacionar con tales conceptos. En este sentido, lo opaco y oscuro permitirían una comprensión más amplia de la que se tiene hoy día con el significado que se le da a un determinado concepto. Pero, también, como dice Heidegger, en el párrafo que sigue al texto citado, se corre un gran peligro cuando la filosofía se reduce a filosofar con palabras y no con cosas, no con el ente mismo, es necesario aproximarse al ser (de las cosas) y no quedarse en palabras y conceptos. 
Hay entes que, en su específica manera de ser, tienen la peculiaridad de darse como algo que no son o como caracterizados como lo que no son. Así, por consiguiente, la posibilidad del error no se encuentra primariamente en una aprehensión equivocada, sino en el ente mismo. (Heidegger, 2006, p. 50)

Lo dicho no resta verdad al hecho del error que emerge lingüísticamente; sin embargo, en lo que insiste Heidegger es en que lo falso, lo equivocado, lo erróneo, surge desde la constitución ontológica del ente, que en algunos casos se muestra como lo que no es. Y solo como consecuencia de este sustrato ontológico — por decirlo asíse da también en el habla el error, la equivocación, la falsedad y la mentira. De ahí que Heidegger señale que quien habla tiene la posibilidad de encubrir(se), porque de forma explícita quiere mentir o quiera aparentar que sabe. En síntesis, de lo que se trata en este apartado es de señalar, a partir de un texto aristotélico, que en la mostración fenomenológica del ente devine el ser en sí mismo y también como modo de ser de otra manera, no siendo lo que es, o sea como lo falso, lo erróneo, y que, a su vez, en el lenguaje, se evidencia como error o mentira.

En la tercera sección de Conceptos fundamentales de la filosofía antigua, que como ya se dijo fue un curso dictado en el verano de 1926, Heidegger trata de Aristóteles. Inicia con una reflexión acerca de los dos conceptos fundamentales: ente y ser, para identificar así el problema ontológico (insistimos en que para esa fecha aún no es clara la diferencia ontológica). Encuentra un doble concepto que, por un lado, busca la explicación óntica y, por otro, la interpretación ontológica, pero, de todas maneras, referidos el uno al otro, puesto que ente siempre tendrá un significado determinado por (el) ser, "partiendo siempre de él y retornando siempre a él” (Heidegger, 2014a, p. 181). Debió aclarar Heidegger que lo óntico no dejará de corresponder a una región de todo lo que es (y por ello, ente), mientras lo ontológico es competencia de la universalidad que comprende a todo lo que es (y por ello, ser), propio esto último de la ontología, como lo indica Mörchen en sus apuntes de clase: 
Ninguna de las otras ciencias toma en vista lo que en general hay que decir sobre el ser en su totalidad. Todas las otras ciencias delimitan una región del ámbito universal del ente e investigan lo que pertenece a tal región del ser, lo que es dado en su interior. La geometría trata de un ente determinado, el espacio. Pero aquí la pregunta es por el ser. En la medida en que es científica, investiga los principios que constituyen el ser como ser. (2014, p. 316)

Y así, de la mano de la llamada Metafísica de Aristóteles, Heidegger señala el objeto de la ciencia fundamental (o el objeto fundamental de la ciencia), a saber: el ser, cuya pregunta deberá plantearse de forma independiente de todas aquellas preguntas que interrogan por un ente determinado (Mörchen, 2014, p. 322). Advierte, sin embargo, que esta manera en que se da la ontología no era clara ni en Aristóteles ni en los escolásticos, que el texto de la Metafísica adolece de contradicciones, sobre todo porque confunde el ser y las primeras causas, ontológicamente comprendidas, con entes, "pero tales causas son principios que en sí mismos son fuerzas y otras cosas semejantes y, por tanto, ellos mismos son. La ciencia trata de principios últimos, pero no del ente, sino del ser" (Mörchen, 2014, p. 317), y de los diversos modos del ser llamados categorías (Heidegger, 2014a, pp. 185-189), de cuya diversidad emerge el hecho de la analogía, es decir que el ser se muestra de diversas maneras, que resultan entonces análogas y, por ello, en todos los entes se da de manera natural la analogía, y, también por ello, la analogía será siempre ontológica, porque siempre tendrá su referente en el ser "puro y simplemente dicho, no este o aquel ser, no el ser de un ente determinado, no el ser y este ente, sino el ser puro y simplemente" (Heidegger, 2014a, p. 191).

Con base en su lectura de la Metafísica aristotélica, Heidegger, además, vislumbra los lineamientos del ser en el sentido de "estado-de-encubierto" y "estado-de-descubierto" que sale-al-encuentro (2014a, pp. 194-198), y que por tanto es dinámico (está-en-movimiento). ¿Cuál es la comprensión ontológica que de la potencia y el acto se da en Aristóteles? “¿Cómo llegan la posibilidad y la actualidad a integrar las determinaciones fundamentales del ser, dentro de las que se han 
mantenido en la ontología posterior hasta el día de hoy?", se pregunta el filósofo alemán (Bröcker, 2014, p. 345). Potencia y acto son fenómenos esenciales del movimiento en cuanto este no sea comprendido meramente dentro de los límites ónticos, puesto que la comprensión que acá se exige, según Heidegger, es a nivel ontológico; es decir que lo que se busca es la esencia del movimiento en cuanto tal, en sí mismo (Bröcker, 2014, p. 346).

Ser en acto es ser-disponible (lo que por tradición se ha dado en llamar actualidad), lo presente como disponible-para. Lo-disponible, en movimiento o en reposo, no solo "está presente, ahí" sino que se impone, se pone delante, es una presencia insistente. Ser, en cuanto movimiento, es pura disponibilidad (Heidegger, 2014a, pp. 201-203). Según Bröcker, Heidegger dice:

En la medida en que el movimiento representa un modo más alto de la presencia y en tanto el movimiento determina el ser del mundo y es eterno como esta determinación, resulta que tenemos que ver en el movimiento y en el ser movido la movilidad más alta del ser, a partir de la cual recién entonces solo puede hacerse comprensible el reposo. (2014, p. 352)

Lo que se impone en su presencia, de forma insistente, no puede permanecer en reposo pasivo, se realiza en una naturaleza dinámica que se va mostrando a cada momento, en su ahora; es decir que su naturaleza es también temporal: "La demostración más terminante la lleva a cabo Aristóteles sobre la base del fenómeno del tiempo" (Heidegger, citado por Bröcker, 2014, p. 353). Pero dicha naturaleza dinámica, como presencia a partir de sí misma y constantemente acabada pero sin estar en reposo, es algo así como (la) vida ${ }^{7}$, especie de ser en modo más alto (Heidegger, 2014a, p. 206).

7 Esta referencia, de suma importancia en nuestra investigación, no es tomada de la Metafísica de Aristóteles, sino de su Física (1, 250b-14). Vale la pena resaltar que en Aristóteles, y en algunos apartados heideggerianos, como el que se está comentando acá del curso de 1926, el sentido del ser es vital; es decir, 
El último acápite de este curso está dedicado a la ontología de la vida. Según Heidegger, los lineamientos aristotélicos de una ontología así se encuentran en su tratado "sobre el alma" (De anima), título que

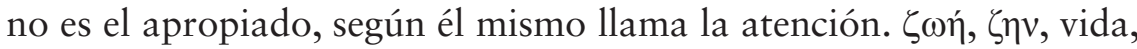
es uno de los conceptos fundamentales, concepto ontológico funda-

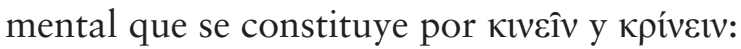

Aristóteles muestra que el punto de partida del movimiento no es la mera percepción de un objeto apetecible. El objeto no es apre-

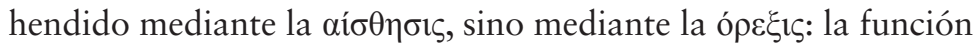
del descubrir la tiene el “apetito". Solo sobre la base del 'орєктóv

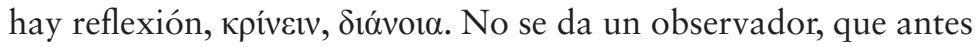
mira alrededor observando y luego se pone en movimiento tras

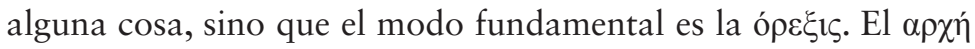
es la unidad de кıveîv y кpíveıv. (Heidegger, citado por Mörchen, 2014, p. 337)

En el ser humano, la vida ( $\zeta \omega \eta$, $\zeta \eta v)$, se da de un modo particular ya que es un ser viviente con la posibilidad de actuar, lo que hace que su

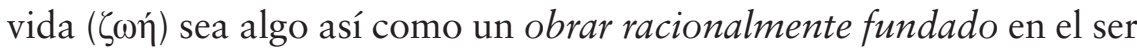
(ßíos): la existencia (Heidegger, citado por Mörchen, 2014, p. 339). Pero esto no fue profundizado por los griegos debido a que la suya era una ontología del mundo, del presente, pero no de la vida en su fundamento radical (pp. 340-341).

Más o menos un año después, en el curso que dictó en la Universidad de Marburgo: Los problemas fundamentales de la fenomenología (que puede considerarse la tercera sección anunciada de Ser y tiempo, aunque también inconclusa), cuando estudia el problema ontológico de la cópula en las oraciones, es decir, la referencia al ser desde los enunciados lógicos, expresa que se da una relación profunda entre la verdad que se enuncia y el verbo copulativo, lo que exige una interpretación

el concepto de ser conlleva una compresión de la dinámica vital, del acto de la vida que se realiza en cada ahora por fuerza de sí misma. 
ontológica (Heidegger, 2000a, p. 224). Las proposiciones de la forma "S es P" evidencian el verbo ser en cuanto cópula que une, que relaciona un sujeto con un predicado y, en este sentido, ser no tiene un significado independiente sino que significa una relación, es decir: cosignifica. "De este modo, el ser expresa la relación misma" (Heidegger, 2000a, p. 225), una cierta unión. Dicha unión o relación evidencia aquello que en otro apartado del curso Heidegger explicitó y argumentó de manera fehaciente: ser no es ente, entre ser y ente se patentiza la diferencia ontológica. De ahí que en el lógos el ser se muestre como síntesis racional, el ens rationis de la filosofía aristotélico-escolástica interpretando a Aristóteles (Heidegger, 2000a, p. 227).

\section{La Edad Media}

Como es sabido, para Heidegger, la metafísica es, ya desde los griegos, la historia del olvido del ser, de ahí que todo el medievo no sea más que eso, mero olvido del ser: hay metafísica pero no ontología. De la escolástica señala a tres grandes pensadores: Tomás de Aquino, Duns Scoto, y Francisco Suárez; y resalta la obra de este último por ser el primer pensador en sistematizar la filosofía medieval, particularmente la ontología (Heidegger, 2000a, p. 112). Su obra clásica son las Disputaciones metafísicas; cuya primera parte, de la disputa 1 a la 27 , trata del ser en general y de sus propiedades; mientras que la segunda parte, de la disputa 28 a la 53, se ocupa del ser de determinados entes, diferenciando allí el ente infinito (Dios) del ente finito (criatura), y la disputa 54 trata del ente de razón (ser ideal). Indudablemente la metafísica de Suárez es teocéntrica como toda la metafísica escolástica:

Dios en tanto que el ente primero y principal es también el objeto primario de toda la metafísica, es decir, de toda la ontología, y el primum significatum, aquello que es significado primero, es decir, lo que constituye el significado de todos los significados; el primum analogatum, o sea, aquello a lo que se refiere toda proposición enunciativa sobre el ente y toda comprensión del ser. La 
antigua convicción dice: puesto que todo ente que es efectivo viene de Dios, la comprensión del ser del ente debe remontarse, en definitiva, también a Él. (Heidegger, 2000a, p. 114)

Suárez explica que la distinción de Agustín de Hipona en la que se comprende al ente como infinito o finito, también puede ser ens a se y ens ab alio, el ente que es por sí mismo y el ente que es por otro. Distinción que en el fondo es neoplatónica, y por ello le corresponde la del ente necesario y ente contingente, ente por esencia y ente por participación, o ente increado y ente creado. También está la distinción entre ente efectivo (acto puro) y ente potencial (posible), aunque se aclara que todo ente efectivo (excepto Dios) también es posible o tiene la posibilidad de ser. "A partir de esta distinción, implícitamente presente por doquier, incluso donde no se la menciona, comprenderemos el problema escolástico" (Heidegger, 2000a, pp. 114-115), el ente infinito es necesario, no puede no ser, luego es efectivo, su esencia es su existencia, mientras el ente finito existe solo dentro de la posibilidad que le participa el ente infinito, su efectividad es accidental.

También es propia de la escolástica la distinción entre el concepto formal y el concepto objetivo del ente. Si la forma es aquello que convierte algo en efectivo, lo es en el sentido de la concepción: la forma no es algo vacío ni secundario, sino aquello por medio de lo cual se concibe algo (como en Hegel, para quien pensar y ser son lo mismo, porque el concepto de ser radica precisamente en su concepción). El concepto formal del ente "es concebir el ente o, de manera más general y cuidadosa: aprehender el ente" (Heidegger, 2000a, p. 116). En la concepción o aprehensión se encuentra el objeto que se concibe, es decir, el contenido del concepto, la ratio entis, el significado.

Según Suárez, en pleno acuerdo con Tomás, el objeto de la ontología general es el conceptus objectivus entis, el concepto objetivo de ente, es decir, lo universal en el ente como tal, el significado de ser en general tomado en su abstracción más completa, o sea, independiente de toda referencia a cualquier ente determinado. Este concepto de ser es, de acuerdo con la concepción de la escolástica y de la filosofía en general, la ratio abstractissima et simplissisima, 
lo más vacío y simple, eso es, lo más indeterminado y simple, lo inmediato. (Heidegger, 2000a, p. 116)

Y ¿cómo comprender este ens en el contexto de la escolástica? En una primera aproximación (lingüística) ens no es otra cosa que 'ente': algo con subsistencia, con efectividad. Tiene significado de participio del verbo ser, como 'sido', lo-efectivo, lo-que-existe (ahí): un modo de ser, en cuanto existencia. Pero también significa lo-realizado, lo-real, la realidad (total), en su esencia total. "Todo lo que es, es ens y res. Es decir, tiene ser y tiene ser como esto o aquello" (Heidegger, 2000a, p. 117), tiene ser o existencia, y aparece como realidad, como cosa, con una esencia concreta (essentia realis, constitución quiditativa: quidditas).

Heidegger se detiene en esta segunda acepción: la quidditas es la respuesta a la pregunta “¿qué es (esto)?”, cuándo (esto o eso) es lo que era el ser (de Aristóteles), la esencia que se apaña en la definición de los entes, lo que hace que ese ser no sea todo el ser sino un ser concreto y determinado, con su figura apropiada, con su naturaleza propia. La esencia, o en términos escolásticos, la esencia real "es aquello que es pensado propiamente en el esse, en el ser de un ens, de un ente, si es captado en su efectividad" (Heidegger, 2000a, p. 119).

En contraste con la esencia también se tiene la existencia. Un contraste bastante escolástico, pero poco y nada griego. Heidegger cita a Tomás de Aquino quien, en la Suma de teología, define el esse como actualidad o efectividad de toda naturaleza, de toda forma, de toda esencia. Así, el ser es actualidad, algo existe si es acto, el carácter de efectuado del ser; es decir, existencia. No la existencia-humana (como en el alemán de Heidegger que tiende a confundir existencia con Dasein): "La existencia (existere), en este amplio sentido, no en el que lo tomamos nosotros como modo de ser del Dasein, sino en el sentido de subsistencia" (Heidegger, 2000a, p. 120), existencia como carácter de efectuado, efectividad, efectivamente dado, presente ya ahí (situado), como independiente de sus causas.

De esta manera, la filosofía escolástica hace claridad entre lo que es y si es: entre esencia y existencia. La pregunta por el ser queda comprendida, entonces, en la línea de lo que es como esencia y la línea de 
si es como existencia: un qué es y un posible cómo es. "Decimos: un posible cómo porque no se encuentra en el qué de todo ente que este exista" (Heidegger, 2000a, p. 121). Ahora bien, esta comprensión general del problema debe señalarse en las sutiles diferencias entre las diversas acepciones que se dieron en el medievo: una tomista, una escotista y una suareciana, por lo menos.

A partir de un texto de las Quaestiones de quolibet de santo Tomás (II, q.2, a.3), Heidegger evidencia que una cosa es la esencia de un ente y otra cosa es la existencia de ese ente, y de ahí que esta sea considerada una distinción real. "La efectividad es algo que se añade al qué de un ente" (Heidegger, 2000a, pp. 124-125), como en los entes creados su existencia es causada por otro, no puede sino darse realidad a un ente en su efectividad, sobre la potencialidad que tenía y que no es la misma realidad (una sería la realidad potencial y otra la realidad efectiva). Así lo expusieron Gil de Roma, Pedro Lombardo, y Juan Capreolo, entre algunos de los mencionados por Heidegger (2000a, p. 126).

Para los escotistas, en cambio, no se trata de realidades diferentes, sino de la misma realidad en dos modos distintos (distinctio modalis). La existencia de cada ente pertenece a ese mismo en cuanto tal, no es otra realidad, según lo sostuvo el mismo Scoto en su Reportata parisiensia. Así, la existencia añade a la esencia solo un modo metafísico en que se presenta cada ente, el que por naturaleza (en la creación) ya está concebido como tal.

Al realismo tomista y a la "modalidad" escotista se une la distinción de razón de Francisco Suárez. En sus Disputaciones metafísícas (Xxxi) expone cómo entre esencia y existencia se presenta más bien una diferencia conceptual que sigue la línea de Scoto. Suárez se pregunta si en el ente efectivo y real puede darse una diferencia entre su esencia (cuando era solo "posibilidad") y su existencia (ya real), a lo que contesta de forma negativa, porque entonces tendríamos dos realidades diferentes, dos entes, cosa que, como es evidente, no puede ser: tiene que ser, todo ente, ese ente, pues solo de manera conceptual diferenciamos entre su esencia y su existencia. "Suárez traslada a la existencia la sugerencia aristotélica de que, en todo lo pensado, ya se le considere como efectivo o como posible, puede pensarse a la vez el ser" (Heidegger, 2000a, p. 130). Cuando la esencia se realiza en su 
existencia, con la creación, no se comprende como que "lo posible" abandona un modo de ser, sino que ahí, en efecto, recibe - por primera vez-su ser.

\section{Descartes}

El problema de comprensión de la esencia y la existencia, como se ve, va tomando una sutil distancia del problema del ser en cuanto ser. Los filósofos modernos acentuarán dicha distancia, hasta perder todo viso inclusive de trascendentalidad del ente y "caer" en el olvido del ser. Por ejemplo, en Descartes, llamado padre de la filosofía moderna, ni la metafísica ni la ontología son de interés central para avanzar en el problema que le preocupa, a saber, el del conocimiento. "Para la preocupación por el conocimiento reconocido ya no le es visible su auténtico ser. A la preocupación, en su estado normal, le es imposible traer bajo la mirada su auténtico ser" (Heidegger, 2006a, p. 124), aun a pesar de que él considere que sus investigaciones son de filosofía primera. A Descartes le preocupa tanto el problema de la certeza, que el problema de la verdad resulta desplazado. Su interés se orienta al "conocimiento verdadero" que en él es conocimiento cierto, evidente: claro y distinto. "Dentro del planteamiento de partida cartesiano, se pone de relieve una nivelación del concepto de ser, que está orientado en el sentido de perceptum esse" (Heidegger, 2006a, p. 163), como un orden natural del ser del hombre.

Descartes acepta este suelo, pero reinterpreta esta ordinatio naturalis hacia lo verum proponiendo lo verum como certum. Lo certum incluye dentro de sí un concepto de verdad totalmente específico que originariamente solo se adapta a las matemáticas, pero que traspasó su ámbito originario y se extendió hasta alcanzar un dominio absoluto. (Heidegger, 2006a, p. 225)

Es sabido cómo, para Heidegger, la de la metafísica es la historia del olvido del ser. Con el desarrollo de las ciencias en la modernidad, de la mano 
de apuestas filosóficas como la cartesiana, se cierra aún más el horizonte de una ontología que se pregunte por el ser de las cosas y, en general, por el sentido del ser. Es cierto que el ente observable, cuantificable, del que puede tenerse un conocimiento objetivo, posibilita la ciencia; pero es, indudablemente, el camino que condena al olvido de ese preguntar fundamental propio de la ontología. El ser, que se muestra en la verdad, desaparece en Descartes, para quien el problema de un conocimiento cierto responde a su "universal" regla de claridad y distinción. "Lo buscado es lo certum en el sentido de que a Descartes solo le importa encontrar un certum aliquid" (Heidegger, 2006a, p. 228), "en la medida en que lo certum es lo verum. Como lo non verum es lo incertum en sí mismo ya falsum, como falsum es non ens" (p. 230).

Sin embargo, como todo conocimiento lo es en tanto quien conoce se da como conciencia que intelige, el problema del ser aunque no queda por completo objetivado, sí queda radicalmente subjetivado. Con Descartes el problema del ser (esse) se reduce a un problema de soy (sum): "El esse de la cosa que encuentro es un ser que tiene que ser expresado mediante el sum" (Heidegger, 2006a, p. 238). Así las cosas, pareciera que la ontología se redujera a una teoría del conocimiento, teoría que de todas maneras dependería en todos los casos del sujeto que conoce. Con esto, también el problema de la verdad como develación del ser queda reducido a un problema de certeza, con la ilusión de objetividad, que se dibuja sobre la subjetividad de la conciencia cognoscente:

Que la teoría del conocimiento contemporáneo, en conexión con una peculiar oposición a Aristóteles, profese una idea de la verdad en el sentido de la validez, se encuentra en el unitario origen de esta disciplina en Descartes. Esta orientación nos ha llevado a la imposibilidad de comprender algo de lo que Aristóteles comprendió por verdad, y después a pasar a la modificación de este sentido en lo certum. (Heidegger, 2006a, p. 248)

El interés por la objetividad del conocimiento ha devenido, entonces, en la reducción de la verdad por la certeza, pasando por alto que lo 
objetivo se centra en lo ente y pierde en consecuencia su sentido de ser, su horizonte ontológico. El problema de la certeza, como se evidencia, no es el problema de la verdad, así como el problema del ente no es el problema del ser. Pero en Descartes no se ha dado esta claridad y distinción: "El certum esse tiene la primacía de la predicación del ser" (Heidegger, 2006a, p. 253), y con ello se está ratificando el olvido del ser.

\section{Kant}

Heidegger también se interesó por el problema ontológico en Kant. En 1927, en la Universidad de Marburgo, dictó el curso Los problemas fundamentales de la fenomenología (2000a), donde argumenta la tesis de Kant, de que el ser no es un predicado real. Como en alemán Dasein y Existenz traducen al castellano 'existencia', pero Dasein no siempre es el Dasein humano, vale la pena exponer la distinción del uso de estos términos en dicho curso.

Por supuesto, el Dasein humano es el ser humano o sencillamente (el) hombre, único sujeto de la existencia; mientras que los términos Dasein (sin más) y Existenz hacen referencia, no al ser humano que existe, sino al ente que subsiste. Queda así sentada la diferencia conceptual ente existencia y subsistencia con la que se comprende el sentido de que el ser humano existe mientras los entes, las cosas, subsisten.

“¿Qué quiere decir la tesis negativa: el ser no es un predicado real o, como dice también Kant, no es un predicado de una cosa?" (Heidegger, 2000a, p. 59). Kant trata de este asunto tanto en El único fundamento posible, de 1763, como en Crítica de la razón pura, de 1781 y 1787 . Y ya la pregunta misma da cuenta de que lo real es lo que pertenece a las cosas "reales", "determinadas", "concretas", "ahí". "La realidad significa, pues, el predicado dotado de contenido quiditativo que se pone afirmativamente" (Heidegger, 2000a, p. 62). Con estos términos se quiere poner distancia al concepto de realidad objetiva de Descartes, para quien esta significa la realidad esencial y, en este sentido, posible. En Kant, realidad significa realidad objetiva en sí, que pertenece efectivamente a las cosas en cuanto tales. Si la 
posibilidad se dice como "mera posición", y la realidad efectiva como "posibilidad absoluta", según la comprensión de Heidegger de los dos textos kantianos, la conclusión es que "el ser no es, ni en el significado de 'mera posición' ni en el de 'posición absoluta', un predicado real” (Heidegger, 2000a, p. 67).

Heidegger indica que:

A nuestro intento de profundizar más en la interpretación del concepto de ser y, de este modo, esclarecer algo más la explicación kantiana, parece oponérsele una máxima metodológica, que el mismo Kant antepuso a su exposición del concepto de ser [...]. (Heidegger, 2000a, p. 71)

Y a continuación cita a Kant:

[...] por lo que respecta a esa lisonjera idea que uno se hace de que habrá de acertar más que los otros por su mayor agudeza, se comprende bien que siempre han hablado así todos los que han querido sacarnos de un error ajeno para llevarnos al suyo propio [...]. (Kant citado por Heidegger, 2000a, p. 71)

Si en algún lugar Kant expresó su concepción de ser como posición (ser-puesto), las disquisiciones de Heidegger por esta época no parecen ir mucho más allá (2000a, pp. 71-77); sin embargo sí hay algo que tiene muy claro: el ser no es un ente y la comprensión del ser requiere de un modo de aprehensión diferente al de cualquiera de las ciencias, pues la ciencia que investiga el ser, la ontología o filosofía primera, no investiga cosas, su objeto no es la realidad óntica tal cual, sino el ser de esa realidad (Heidegger, 2000a, pp. 77-84). De ahí se deduce lógicamente que el ser no es un predicado real, no es un ente. Vale aclarar que esta "lógica del ser no quiere decir que los problemas ontológicos sean reducidos a problemas lógicos en el sentido de la lógica escolar" (Heidegger, 2000a, p. 104), sino que se entiende en el sentido que ya se aclaró antes de lo que era el lógos griego para Heidegger. 
Detengámonos ahora en una obra de 1929, que Heidegger revisó varias veces, por lo menos en 1950, 1965 y 1973: Kant y el problema de la metafísica (1996). El concepto general de metafísica como conocimiento fundamental del ente como tal y en su totalidad se ha asumido de manera dogmática, dice Heidegger, por dos motivos: uno se deriva de la concepción cristiana del mundo en el que todo ente diferente de Dios es ente creado, entre los cuales hay uno al que le concierne la salvación de su alma: "De esa manera la totalidad de los entes, conforme a la conciencia cristiana del mundo y de la existencia, se subdivide en Dios, Naturaleza y Hombre" (Heidegger, 1996, p. 18). Luego, estas disciplinas se considerarán propias de la metafísica especial, y a la que estudia al ente en general se le llamará metafísica general. El segundo motivo se deriva del modo en que se da el conocimiento: tanto en el caso del ente general, como de sus partes especiales, la metafísica deviene en una ciencia de la razón pura, "su método, hasta aquí, ha sido un mero tanteo y, lo que es peor, un tanteo entre meros conceptos" (Kant citado por Heidegger, 1996, p. 19).

Dentro de los límites de la metafísica especial se debe comprender que todo conocimiento del ente se asienta sobre los fundamentos que ofrece el ser. “El 'plan preconcebido' de una naturaleza en general supone primeramente la constitución del ser del ente, a la cual debe poder referirse toda investigación” (Heidegger, 1996, p. 20), así que la posibilidad de todo conocimiento óntico radica en el conocimiento ontológico. De esta manera, en Kant, según Heidegger, la ontología se convierte en un problema: la metafísica especial con sus ciencias positivas “se fundan en un 'interés más alto', que la razón humana lleva en sí misma” (Heidegger, 1996, p. 21), desde donde se revela la posibilidad más propia de la ontología (porque no todo conocimiento es óntico ${ }^{8}$ ).

8 En Heidegger esto es fundamental. Para él no puede darse conocimiento alguno de los entes si no es gracias al saber ontológico, único saber desde el cual puede comprenderse: "El conocimiento óntico por sí solo no puede nunca conformarse 'según' los objetos, ya que sin el conocimiento ontológico carece de posible dirección”. Las ciencias, todas, dependen siempre del trasfondo ontológico desde el cual los seres humanos nos aproximamos a los entes, a las cosas, a los objetos. Esta es, según Heidegger, la razón de toda crítica. 
"Quien quiera entender la Crítica de la razón pura tiene que grabarse en la mente que conocer es primeramente intuir" (Heidegger, 1996, p. 29). Aproximándose a la obra de Kant, Heidegger señala de manera insistente cómo el pensar va de la mano con la intuición. Llama la atención cómo, en contra de esa tradición conceptualista de la filosofía occidental, el pensador alemán defiende el papel que desempeña la intuición en el filosofar. Y, como es natural, no ignora la noción de intuición, que cita en Kant como "referida inmediatamente al objeto de manera singular", a diferencia del concepto que es mediato y común a varias cosas. De esta forma vendrá a afirmar que el conocimiento es una intuición pensante, que la intuición constituye la esencia del conocimiento y que en la relación recíproca entre intuición y pensar, es la intuición la que tiene el verdadero peso (Heidegger, 1996, p. 30).

El conocimiento del ente es, entonces, intuitivo; sin embargo, este no puede darse sin otro conocimiento independiente de la experiencia, aquel que exige la previa comprensión del ser: "El problema de la posibilidad de la ontología equivale, por consiguiente, a la pregunta acerca de la esencia y del fundamento esencial de la trascendencia de una comprensión previa del ser" (Heidegger, 1996, p. 45). No hay que olvidar, en este contexto, que para Kant el ser no es un predicado real: todo conocimiento del ente conlleva predicados reales en los cuales se predica "algo" distinto del sujeto, algo-real, algo ente o que concierne a lo óntico, fruto de experiencias reales. La experiencia es propia de conocimiento finito, "intuitivamente receptivo del ente. El ente debe ser dado al conocimiento como objeto" (Heidegger, 1996, p. 104). Pero otra cosa es la que se nos da en la comprensión del ser.

Según Heidegger, lo ontológico no hace referencia alguna al ente; la posibilidad del conocimiento, al ser este óntico, se constituye como esquema a priori desde el cual se puede dar todo conocimiento del ente, pero sin ser él mismo óntico. No se darían, como objetos para sujetos los entes, si, de antemano, no se diera la posibilidad comprensora del ser: solo desde un horizonte hermenéutico-ontológico se puede dar el conocimiento y, con él, la ciencia.

"Si el conocimiento ontológico revela el horizonte, su verdad está precisamente en el permitir el encuentro del ente dentro del horizonte" 
(Heidegger, 1996, p. 110), horizonte de comprensión del ser, que en Kant tiene el significado de filosofía trascendental. Por ello la ontología se fundamenta en la imaginación trascendental, raíz de la sensibilidad y del entendimiento. Pero esta sensibilidad y entendimiento son estudiados por Kant como capacidades del ser humano, y esta es la razón por la cual Heidegger insiste en el papel central que desempeña el Dasein humano en la comprensión ontológica del ser en cuanto ser. Es el Dasein aquel ser que siempre se ha encontrado en medio de entes, y esta situación existencial es desde donde se evidencia la precomprensión ontológica que, de todas formas, muestra aspectos óntico-ontológicos como los de esencia, existencia, posibilidad y realidad, entre otros (Heidegger, 1996, p. 188).

Sin embargo, con Kant queda el sinsabor de que se abre una brecha entre lo metafísico y lo ontológico, debido a que ya está lo suficientemente influenciada por el pensamiento subjetivo moderno. Heidegger se da cuenta de ello, y así lo expresa en 1942: "La figura moderna de la Ontología es la Filosofía trascendental que se convierte en Teoría del Conocimiento" del ente, que le es posible conocer a un sujeto pensante. "Se trata de la Metafísica del objeto, es decir, del ente como objeto, del objeto para un sujeto" (Heidegger, 2001, p. 54), donde el problema del ser en cuanto ser queda relegado. Este, el ser, como tal, deja de ser interrogado, y por ello hace falta elaborar de nuevo la pregunta ontológica que haga patente, de todas formas, esa diferencia entre ente y ser, desde la que este último cobra su verdadero sentido. Justo es la pérdida de sentido del ser la que ha llevado en nuestra época a la desvaloración de todo sentido, “las 'guerras mundiales' y su 'totalidad' son ya consecuencia del estado del abandono del Ser” (Heidegger, 2001a, p. 67).

Casi veinte años después, en 1961, Heidegger vuelve a preguntarse por el sentido del ser en Kant —aunque con seguridad no dejó de hacerlo nunca-. En una conferencia ofrecida en Kiel, "La tesis de Kant sobre el ser", se ratifica la misma tesis de que el ser no es un predicado real; tal vez insiste un poco más en el planteamiento del ser como posición, a partir de aquella sentencia de la Crítica de la razón pura: “Evidentemente, 'ser' no es un predicado real, es decir, el concepto de algo que pueda añadirse al concepto de una cosa. Es simplemente 
la posición de una cosa o de ciertas determinaciones en sí" (Kant, 1988, p. 504).

Este concepto de posición es de lo más sencillo, al parecer, tanto para Kant como para Heidegger, e identifica al ser en general; y como el contexto kantiano es teológico (pues se da cuando trata la “imposibilidad de una prueba ontológica de la existencia de Dios"), Heidegger deduce que "la tesis sobre el ser no es ninguna enseñanza abstracta" (Heidegger, 2007d, p. 365), a pesar de la manera episódica en que se presenta en la Crítica. En fin, en lo que insiste Heidegger en la citada conferencia de 1961 es en la comprensión de ser como posición, posición-delante-de un entendimiento para el que es sujeto el ser, ya que Kant piensa el ser en relación con la facultad del entendimiento (horizonte moderno ya señalado anteriormente). Desde ahí dicha posición puede significar realidad efectiva, tanto como posibilidad, y entonces es "ser: en realidad, lo que permite la presencia" (Heidegger, 2007d, p. 387). De todas maneras, nada es definitivo. Siempre la pregunta. Ya finalizando la conferencia de nuevo se interroga: “ ¿Qué significa aquí presencia? ¿Actualidad? ¿Cómo se puede determinar algo así? ¿Acaso se muestra aquí, o mejor dicho, se esconde un carácter impensado de una esencia oculta del tiempo?” (Heidegger, 2007d, p. 388).

\section{Hegel}

En el semestre del invierno entre 1930 y 1931, Heidegger dictó el curso La fenomenología del espíritu de Hegel (2006b), que se publicó solo hasta 1980. En la introducción hace bastantes aclaraciones, una de las cuales tiene que ver con el sentido de la ontología para Hegel, según el cual el sistema de la ciencia se estructura en dos partes, a saber, una primera, la fenomenología del espíritu, y la segunda parte:

[...] no debía contener únicamente a la Lógica, sino a la Lógica al unísono con las ciencias reales de la filosofía. Pero ese todo que debía configurar la segunda parte del sistema no es otra cosa que el concepto transformado de la metafísica transmitido por la tradición, cuyo carácter intrínseco sistemático también determinó de parte a 
parte la problemática kantiana: metaphysica generalis: ontología; metaphysica specialis: psicología especulativa, cosmología especulativa, teología especulativa. (Heidegger, 2006b, p. 14)

Esta última, la teología especulativa, es en verdad ontología del ens realissimum, ente que es Dios. En últimas, su concepto de sistema de la ciencia variará pero manteniendo esta idea de base, en la cual la ontología no juega un papel diferente al que desempeñó para Kant. El problema del ser en cuanto tal sí tendrá en Hegel su propia particularidad. En su sistema racional, la pregunta por el ente está conectada al lógos porque es desde el mismo lógos que emerge dicha pregunta (Heidegger, 2006b, pp. 26 y 98). La autoexposición de la razón, que es autoexposición del espíritu, está conducida por el problema fundamental de toda la filosofía: por la pregunta por el ser (Heidegger, 2006b, p. 64).

Sin embargo, cuando Hegel usa los términos ser y ente solo contempla una determinada región del ente, para un determinado modo de ser. "Lo que Hegel denomina el ente y el ser, nosotros lo designamos con las palabras 'lo que está presente ante la mano' y su 'ser presente ante la mano" "' (Heidegger, 2006b, p. 65), que podríamos asimilarlos en lengua castellana como presente y presencia, aunque con un sentido tal vez más óntico que ontológico.

El ente en sí mismo es entendido como objeto, mientras que el ente para otro, como otro que busca entender ese ente, es el concepto. De todas formas, el objeto lo es del concepto así como el concepto lo es del objeto, son algo así como interdependientes, si no identificables, momentos del lógos, de la razón, del espíritu, del ser, que a su vez se identifican con el saber, "saber de lo inmediato o del ente" (Heidegger, 2006b, p. 79):

9 Llama la atención el comentario que hace Heidegger en el mismo texto: "Pero que Hegel utilice en este momento las palabras 'ente' y 'ser' con esa significación limitada y en verdad limitada de una forma totalmente determinada, no es el capricho de una elección terminológica casual, ni tampoco la terquedad en la propia creación terminológica, tal y como se imagina la plebe filosófica, sino que en ello radica ya una respuesta al problema relativo a la Cosa del ser, tal y como lo plantearon los antiguos" (2006b, p. 65). 
Lo enunciado es la verdad y a la inversa. Así, la verdad es enunciada no solamente ocasionalmente, sino que la verdad es en sí lo enunciado, la proposición. La verdad de la certeza sensible es en cada caso este ente que ella pretende fijar y pretende fijar a ello, pretende fijar a esto, como lo que está presente ante la mano; alude a ello, a esto que es. "Que es": tal es el enunciado de la certeza sensible, su verdad. La certeza sensible enuncia el ser presente de lo que está presente ante la mano; en la terminología de Hegel: el ser. (Heidegger, 2006b, p. 85)

Así que el ser se enuncia dentro del horizonte de la certeza sensible y no es considerado por Hegel como una cuestión abstracta, tanto por las razones ya presentadas, como también porque, para él, quien piensa de modo abstracto es el hombre inculto, no el culto, como lo señala Heidegger con una cita textual (2006b, p. 87). Aprehender de forma especulativa el ser, avanzar en su exégesis, es ontología, donde el ente —en Hegel- es absoluto: Dios. De ahí que dicha exégesis sea onto-teo-logía. Sin embargo, Heidegger señala que esta característica no pertenece solo a Hegel, sino a toda la metafísica, incluidos los griegos con su pensamiento metafísico (2006b, pp. 141-144); mientras que la ontología mira las cosas entendiendo al ente independientemente de cualquier sujeto.

En la Fenomenología del espíritu el objeto del entendimiento se caracteriza como fuerza, porque la realidad efectiva de las cosas, en esencia, es fuerza, porque la cosa se da en sustancialidad, causalidad y acción recíproca, tríada a la que Hegel llama relación. Y solo en esta relación intrínseca de cada cosa se evidencia su esencia como fuerza. Una fuerza que es objeto del entendimiento y que en él es relación. Y una relación que, manteniendo la identidad desde el esfuerzo de separación al interior de la cosa misma, tiende al infinito, "superando así a la aprehensión finita intelectual del entendimiento presente en Kant” (Heidegger, 2006b, p. 151). Fuerza es, entonces, relación, y viceversa.

De ahí que, a su vez, no hay una fuerza: fuerza es siempre fuerzas, varias, juego de fuerzas, hacia sí (ser-para-sí) y hacia fuera (serpara-un-otro), porque "la fuerza es justamente aquello en lo que tiene 
su consistir al unísono el ser-para-sí del estar-en-el-interior-de-sí-presionado y el ser-para-un-otro, es decir, el ser de lo otro mismo como tal" (Heidegger, 2006b, p. 166). Tampoco es que las fuerzas sean algo así como extremos que halan cada una para su lado: al contrario, la fuerza es ese intermedio que se realiza en el juego de "las fuerzas". No hay extremos sustanciales desde-los-que..., solo hay fuerza en su juego efectivo: "Lo realmente efectivo no son las fuerzas aisladas en tanto que sustancias, sino que lo realmente efectivo es el juego de las fuerzas" (Heidegger, 2006b, p. 167). Lo verdadero es el juego, el medio, la relación, no los extremos "sustanciales". Y es en este medio, en este juego, que el entendimiento ve lo que las cosas son en sí, el ser del ente.

No hay, en consecuencia, fuerzas singulares, de un solo vector. En el juego de las fuerzas desaparece toda fuerza singular. Y por esto, el ser de la fuerza es desaparecer. Parecía ser la fuerza, pero la fuerza no es, desaparece en el juego de fuerzas. "El ser de la fuerza es en él mismo un no-ser, apariencia” (Heidegger, 2006b, p. 169). La aparición (lo que aparece) es más que mostrarse o manifestarse, es también parecer-y-desaparecer. En la dinámica de la aparición llega el momento de la desaparición. Una dinámica dialéctica, como es evidente, en la que el espíritu es verdad (lógica), es saber (lógos), es Dios (TEos), y es realidad-efectiva (ente, ov).

Tiempo después, en 1958, Heidegger dictó la conferencia "Hegel y los griegos" (2007e), en la cual se refirió a los orígenes de la filosofía (los griegos) hasta su consumación (Hegel). Ser y pensar son lo mismo para Hegel, porque en el pensar se retoma todo lo que es, "para el pensar no existe nunca nada sabido” (Heidegger, 2007e, p. 347). Se piensa el ser: el sujeto (pensante) se dedica al ser (objeto) encontrando la unidad en(tre) los opuestos, de forma dialéctica (método). Es lo que hicieron los griegos: Parménides con la unidad, Heráclito con el lógos, Platón con la idéa, y Aristóteles con la enérgeia. La unidad de ser y pensar señalada por Hegel es tomada de Parménides, bajo un horizonte cartesiano; el lógos de Heráclito es transformado en la lógica de Hegel como unidad dialéctica entre sujeto y objeto; con las idéas de Platón se inicia la ciencia filosófica, según Hegel, al ponerse fuera y exponerse, y por último, la enérgeia aristotélica es negación que se niega a sí misma, efectividad absoluta y absoluto saber del espíritu, de donde se 
comprende la filosofía como lo más opuesto a lo abstracto, pues su meta es la verdad. "Verdad es para Hegel la absoluta certeza del sujeto absoluto que se sabe a sí mismo" (Heidegger, 2007e, pp. 354-355).

En este contexto, el ser es ese primer ir hacia fuera en el que se expone el espíritu: verdad única que en efecto se "dice" (lógos), viniendo así a la presencia, "es decir, el permanecer ahí delante saliendo fuera del ocultamiento y entrando en el desocultamiento" (Heidegger, 2007e, p. 356). Y desocultar es verdadear. Verdadea el ser cuando se piensa: desde los griegos hace presencia en el pensar el ser que verdadea.

\section{Nietzsche}

En 1961, Heidegger publicó dos volúmenes dedicados a Nietzsche (Nietzsche, I, 2000b; Nietzsche, II, 2000c). Se trata de textos preparados, en su mayoría, para los cursos que dictó entre 1936 y 1946. El influjo de este pensador sobre la apuesta ontológica de Heidegger es amplio, en tal grado que la última parte del segundo tomo expone más bien sus propias ideas sin hacer referencia explícita a Nietzsche, lo cual ya señala un sentido por el hecho de publicarlas allí. El llamado "segundo Heidegger" tal vez no sea más que el mismo filósofo empeñado en la pregunta por el ser, pero que se abre bajo el horizonte de la filosofía nietzscheana ${ }^{10}$.

Heidegger parte de la idea de que, para Nietzsche, el carácter fundamental de todo ente es la voluntad de poder: "Todo ente que es, en la medida en que es, es voluntad de poder" (2000b, p. 31), e incluso la identifica con el ser. Al referirse a la filosofía como "el pensamiento más grave”, dice que Nietzsche está hablando del ser, es decir de la

10 Por esta misma razón se comprende aquí, de manera "compacta”, el conjunto de escritos que presentan los citados volúmenes: Nietzsche. La voluntad de poder, de 1936-1937; La posición metafísica fundamental de Nietzsche en el pensamiento occidental, de 1937; La doctrina nietzscheana de la voluntad de poder como conocimiento, de 1939; Nietzsche: el nibilismo europeo, de 1940; La metafísica de Nietzsche, de 1940, publicado luego junto a Pensar y poetizar, texto nietzscheano que fue el último que ofreció como profesor catedrático. 
voluntad de poder como eterno retorno, devenir fundado en el ser en cuanto ser (2000b, p. 32), según lo expresa en el n. 617 de La voluntad de poder: "Imprimir al devenir el carácter de ser, esa es la suprema voluntad de poder" (Nietzsche citado por Heidegger, 2000b, p. 32).

Antes de avanzar en el objeto de su investigación, Nietzsche antepone en el libro primero una exposición del nihilismo ${ }^{11}$, comprendido como el carácter fundamental del acontecer en la historia occidental, pues no resulta siendo más que la desvalorización de los valores. El nihilismo no es pues, en este sentido, una actitud de una determinada época, ni es un movimiento de un siglo determinado, sino que deviene desde la antigüedad y continúa avanzando hasta nuestros días. El nihilismo destruye formas de ser y posibilita otras de manera creativa, y por ello se habla de "transvaloración de los valores". Al respecto Heidegger señala que es Nietzsche quien indica que hay que ver las cosas como son, que su tarea es sacar a los seres humanos de la apariencia, porque ellos mienten sobre lo que es y por eso no hay sed de lo que debe ser: si la voluntad de poder se deja guiar vitalmente, nuestro deber ser será inspirado por el ser (Heidegger, 2000b, pp. 38-43).

¿Qué entiende el propio Nietzsche con la expresión "voluntad de poder"? ¿Qué quiere decir voluntad? ¿Qué quiere decir voluntad de poder? Estas dos preguntas son para Nietzsche solo una; porque para él la voluntad no es otra cosa que voluntad de poder, y poder no es otra cosa que la esencia de la voluntad. Voluntad de poder es, entonces, voluntad de voluntad. (Heidegger, 2000b, p. 46)

Según Heidegger, esta voluntad de poder nietzscheana es la esencia del ser, que sigue siendo siempre lo más buscado y lo que hay que determinar; pero aclara que dicha voluntad es "afecto", "pasión”, “sentimiento", “orden”, es vivo querer: “Quien solo desea de la manera más

11 Igualmente, iniciando el volumen II, Heidegger vuelve a tratar extensamente el tema del nihilismo (capítulo v), en donde los interesados podrán detenerse y profundizar al respecto. 
pura, precisamente no quiere" (2000b, p. 49). En el querer se integran lo querido y el que quiere; querer es estar resuelto a aquello que se quiere, y en el querer está puesto como querido. En definitiva, lo que se quiere es (el) ser, que en Heidegger siempre es el ser del ente: "De lo que se trata en la pregunta por la voluntad de poder es de la pregunta por el ser del ente" (2000b, p. 52), porque de no ser así, dice, no diría más que algo vacío.

Sin embargo, el ente, en este contexto, es biológico, y su concepto, así como el de voluntad, se concibe desde la vida del sentimiento (Heidegger, 2000b, p. 61). Concebir es saber, no es solo conocer. Para Nietzsche, quien conoce no conoce el saber. El saber no trata de mero conocimiento de conceptos, sino que concibe el ser, se ex-pone al ser, pre-sencia. La voluntad es comprendida, entonces, como querer-sermás, y, citando a Nietzsche en el n. 702 de La voluntad de poder: "Lo que quiere el hombre, lo que quiere la parte más pequeña de un organismo viviente, es un plus de poder". Se podría decir: saber es querer, como querer es saber, no solo conocer, porque es voluntad, no apenas conocimiento de conceptos.

La pregunta por la voluntad de poder exige, en Heidegger, la pregunta fundamental de la filosofía, a la que llama "la pregunta conductora": ¿qué es el ente?, esta es la penúltima pregunta, porque la última es la primera: ¿qué es el ser? Pregunta que es fundamental de la filosofía porque solo con ella se cuestiona sobre el fundamento del ente, a saber, el ser. Ambas preguntas, la conductora y la fundamental, interrogan por el "qué es", ambas se abren "por". En ellas se da la apertura, ¿a qué?, a su des-ocultarse, es decir: a la verdad. Estas dos preguntas interrogan por el qué son, en verdad, el ente y el ser. Pero al preguntar por "la verdad de", surge la pregunta por esa misma verdad: ¿qué es la verdad en la que se des-oculta el ser? Sin embargo, en la esencia del ser está la voluntad de poder, como se dijo renglones atrás, y por ello en la pregunta por la voluntad de poder comparece la pregunta por el ser:

Y si, dentro de la tarea de la interpretación global de todo suceder como voluntad de poder, al arte le corresponde, según Nietzsche, 
una posición destacada, entonces resultará que precisamente aquí la pregunta por la verdad tendrá que desempeñar un papel preponderante. (Heidegger, 2000b, p. 74)

Para Nietzsche, el ser artista es el más transparente, según el n. ${ }^{\circ} 797$ de La voluntad de poder. El modo de ser del artista es la vida misma, voluntad. El arte, al ser creación y destrucción, no es otra cosa que voluntad de poder. El arte es la auténtica tarea de la vida, es actividad metafísica de la vida, y siendo así es carácter fundamental del ente. Al arte, como al ente, le es propio lo sensible, la verdad que se des-oculta en el ente, lo verdadero que otrora se creyó error o falsedad. El arte es donde el ente en su totalidad se revela: desde el mundo sensible, desde el mundo real, desde la voluntad de poder. "La voluntad de lo sensible y de su riqueza es, en cambio, para Nietzsche, la voluntad de aquello que busca la 'metafísica'. Esta voluntad metafísica es realmente efectiva en el arte" (Heidegger, 2000b, p. 79).

Lo suprasensible le quita la vida a lo sensible y este pierde fuerza, se debilita; el arte crea, produce: es un saber (Heidegger, 2000b, p. 86) que rompe los límites de la verdad (de lo que cierta tradición identifica como la verdad), y es una fuerza. "Lo que Nietzsche llama aquí 'fuerza' es la capacidad de la existencia histórica para asumir y llevar a cabo su más elevada determinación esencial" (Heidegger, 2000b, p. 115), de donde se infiere que hay fuerza en la mirada del artista, fuerza vital que embriaga. Una embriaguez que se presenta como estado estético fundamental, desde donde se proyecta la belleza que anima los estados de creación, determinándolos y conformándolos en un placer vital que se vuelve de nuevo a la posición inicial de embriaguez vital: jarte, forma de la voluntad de poder! (Heidegger, 2000b, p. 122; 2000c, pp. 255-258).

$\mathrm{El}$ arte es el acontecer fundamental dentro del ente en su totalidad, según una proposición nietzscheana que estudia Heidegger. Acontece el arte como ente, dentro del ente, por su sensibilidad. La verdad, en sentido tradicional, es suprasensible; la verdad del ente, y con ella la verdad del arte, es la verdad sensible, evidente, y por ello es fundamental. “¿Qué quiere decir aquí 'lo sensible’? ¿Qué tiene que ver con la 'verdad'? ¿Cómo puede tener un valor incluso más elevado que ella? 
¿Qué quiere decir aquí 'verdad'? ¿Cómo determina Nietzsche su esencia?” (Heidegger, 2000b, pp. 139-140).

El nihilismo, desde Platón, ha dado un lugar suprasensible a la verdad y con ello ha demeritado al ente. Por ello lo que busca Nietzsche es superar el platonismo: quiere, entonces, pasar lo que estaba debajo y que se convierta ahora en el punto de la medida, y con ello lo sensible se convierte entonces en lo auténticamente ente, en lo verdadero (Heidegger, 2000b, p. 151), mientras que para Platón el arte estaba lejos de la verdad porque se reducía a mera apariencia (2000b, p. 178). En Nietzsche, como Heidegger lo presenta, se efectúa su anunciada transvaloración, y con ella la belleza del arte verdadea, la sensibilidad del arte con su medida de belleza — por decirlo así- des-oculta la verdad de lo que es: "Verdad y belleza están en su esencia referidas a lo mismo, al ser; se copertenecen en lo único y decisivo: revelar y mantener revelado el ser" (2000b, p. 188).

¿Cómo realiza Nietzsche ese proceso de inversión? Primero, se dice que el mundo verdadero es alcanzable solo para el sabio, para el virtuoso. Segundo, ese mundo prometido a los virtuosos por ahora es inalcanzable. Tercero, aunque inalcanzable y no más que mera promesa, el mundo verdadero se ha convertido en un imperativo, una obligación, un consuelo. Cuarto, si ese mundo es inalcanzable, es inalcanzado, y por tanto es desconocido. Quinto, con todo esto, lo único que hay que hacer es suprimir semejante mundo. Sexto, suprimido el mundo "verdadero" también se suprime el mundo aparente... y quedamos en nada (Heidegger, 2000b, pp. 192-196). No puede ser entonces este el camino a seguir. No hay que suprimir ni un mundo ni otro. Lo que hay que eliminar es "la difamación de lo sensible, así como el exceso de lo suprasensible" (Heidegger, 2000b, p. 197).

De lo que se trata es de despejar el camino para que lo sensible sea interpretado de forma renovada dentro de un nuevo orden jerárquico (transvaloración de los valores) que aprecie como verdadeantes tanto lo sensible como lo suprasensible. ¿Y cuál sería la vara con que se mide la verdad? Lo viviente, en cuanto mirar previo que configura un horizonte de comprensión. Solo en este contexto se comprende la sentencia de Nietzsche n. ${ }^{\circ} 493$ de La voluntad de poder: "Verdad es la especie de error sin la cual una determinada especie de seres vivientes no podría 
vivir. El valor para la vida decide en última instancia" (citado por Heidegger, 2000b, p. 201). La verdad es, entonces, algo así como una apariencia necesaria para que acaezca la vida. Y con esto no se quiere decir, aclara Heidegger, que la verdad sea algo aparente, sino que brinda la perspectiva de lo que aparece como real: es un dejar aparecer, es un aparecer, realidad como apariencia. La verdad es, así, un $p a-$ recer en el que la vida se ofrece bajo un horizonte y en él se conserva.

Si lo "metafísico" no significa otra cosa que la esencia de la realidad, y esta reside en el aparecer, comprenderemos ahora la frase que cierra el capítulo sobre el arte de La voluntad de poder (n. ${ }^{\circ} 853$ ): "el arte como la tarea propia de la vida, el arte como actividad metafísica de la vida”. (Heidegger, 2000b, p. 203)

Con esto, "vida" también resulta transvalorada: ya no se comprende en un sentido "biológico" sino metafísico. Vida se corresponde con ser, aunque se refiera apenas al ser del ente; y este es un saber más elevado que abre el nuevo horizonte para la comprensión del ser (Heidegger, 2000b, pp. 206-207).

¿Y dónde quedó la fuerza? A ella vuelve cuando explica el eterno retorno de lo mismo. La fuerza es el carácter general del mundo, del cosmos. Así, por esencia, es finita, según Nietzsche. El mundo no se sostiene sobre un espacio vacío que no existe: todo es fuerza. El espacio entero es apenas una construcción imaginaria, mientras que el vacío sí podría hacer parte de la esencia del ser (Heidegger, 2000b, p. 283). ¿Por qué ponerle un sentido virtuoso, es decir, humano, al mundo? No es necesario. El eterno retorno de lo mismo, en cuanto devenir que obedece a su propia fuerza, es suficiente (Heidegger, 2000b, pp. 297-301): según Nietzsche, la voluntad de poder depende del eterno retorno de los mismo porque este es "el fundamento y la esencia de la voluntad de poder" (Heidegger, 2000b, p. 344), ambos se copertenecen.

Debido a que el eterno retorno de lo mismo es devenir que acaece por fuerza propia, es él el que brinda el horizonte de comprensión del ente en su totalidad, y por ello es acá donde se centra el pensamiento metafísico de Nietzsche: "Metafísica es aquel cuestionar y buscar 
que está siempre conducido por la pregunta única: ¿qué es el ente?” (Heidegger, 2000b, p. 365). Dicho preguntar emerge de una posición metafísica fundamental por la cual el que pregunta queda integrado estructuralmente en lo preguntado y codeterminado en la totalidad del ente.

Ahora bien, explica Heidegger, si se parte de las dos proposiciones fundamentales de Nietzsche, a saber: que el ente en su totalidad es voluntad de poder, y que el ente en su totalidad es eterno retorno de lo mismo, el "es" no significa lo mismo en cada caso. En el primero se nos señala la constitución del ente; en el segundo, su modo de ser, de todas maneras copertenecientes el uno al otro en ambas proposiciones. Pero, señala también Heidegger, la constitución del ente exige siempre el modo de ser en que se constituye, es decir, lo necesita como su fundamento. Por esto la filosofía de Nietzsche se presenta como "el final de la metafísica, en la medida en que vuelve al inicio del pensar griego, lo recoge a su manera y cierra así el círculo que forma en su totalidad la marcha del preguntar por el ente en cuanto tal" (Heidegger, 2000b, p. 373). ¿Y por qué "el final de la metafísica"? Porque es en Nietzsche donde se conjuga el ente como lo que es siendo, en cuanto (cosa) presente y evidente (que es), y en cuanto siendo como devenir, como lo que acaece en su eterno presente. Constitución y modo de ser.

La síntesis de la metafísica nietzscheana se presenta, según Heidegger, en la sentencia n..$^{\circ} 617$ de La voluntad de poder, que se presume data de 1886, titulada "Recapitulación": "Imprimir al devenir el carácter del ser, esa es la suprema voluntad de poder [...]. Configurar como ente al devenir de manera tal que se conserve como devenir y tenga existencia consistente, es decir, sea" (Heidegger, 2000b, pp. 374-375), donde dicha transformación en ente de lo que deviene es la suprema voluntad de poder. Que lo que deviene se convierta en ente quiere decir que el devenir se realiza en sus más propias posibilidades, transfigurándose existencialmente, es decir: ganando una existencia consistente. Dicha transfiguración es el proceso de la más alta transformación ontológica que pueda darse, que, dicho en una palabra, es crear. "La instantaneidad del crear es la esencia de la eternidad real, efectiva, que alcanza su mayor rigor y amplitud como instante de la eternidad del eterno retorno de lo mismo" (Heidegger, 2000b, p. 375). 
Estas reflexiones de Heidegger son de 1937, más de cincuenta años después de la sentencia de Nietzsche. La suprema voluntad de poder está en “imprimir al devenir el carácter del ser”, según Nietzsche. ¿Qué le dice esto a Heidegger? Que se transfigura en ente lo que deviene, que dicho devenir en ente se da en el instante de creación por el que el devenir se presenta como existencia al realizarse en sus posibilidades (venir a ser) y que como instante (creador) no puede ser más que eterno retorno de lo mismo. ¿Podría dudarse de esta interpretación heideggeriana? El mismo Heidegger trae a cuento la segunda parte de la sentencia: "Que todo retorna es la más extrema aproximación de un mundo del devenir al mundo del ser”.

En su pensamiento más esencial, en el pensamiento del eterno retorno de lo mismo, Nietzsche fusiona en una las dos determinaciones fundamentales del ente que provienen del inicio de la filosofía occidental: el ente como devenir y el ente como consistencia. (Heidegger, 2000b, p. 376)

Con este volver al inicio, hay un círculo que se cierra. ¿De qué manera? Algo nos dice Heidegger. Por ahora baste mantener esta determinación con máxima claridad: en los orígenes de la filosofía occidental, Heráclito y Parménides ostentaron posturas diversas respecto del ser del ente; ahora, con Nietzsche, se logra comprender la fusión de dichas posturas, o más que de las posturas, de la "realidad" en que el devenir se "hace" ente; es decir, del cómo el ente existe realizando las posibilidades del ser. ¿Qué se concluye? Que "al volver el pensamiento metafísico de Nietzsche al inicio, el círculo se cierra" (Heidegger, 2000b, p. 377). ¿Y qué nos queda? ¿Tal vez, pensar "nuevamente" el ser? Pero, tal vez, en estas condiciones el pensador prefiera callar. Nótese que acá habla Heidegger del pensador, no del filósofo. "Al callar, el pensador se coloca a su manera en el rango del poeta" (Heidegger, 2000b, pp. 378-379).

Es posible que acá, a esta altura de la disertación, deberíamos callar. Y sí que se hace necesario para dedicarnos a pensar. Lo que se busca es pensar el ser, o por lo menos el problema del ser. Este es 
el propósito de la ontología, y nada más. Sin embargo, en la historia de la filosofía se evidencia que el ente es algo así como una fuerza de gravedad para el ser: tras la comprensión del ser debemos habérnoslas con el ente, de ahí la metafísica. "Todo el pensar occidental, desde los griegos hasta Nietzsche, es un pensar metafísico" (Heidegger, 2000b, p. 387).

El pensar de Nietzsche logra el acabamiento de la metafísica. "Acabamiento [quiere decir] que todos los poderes esenciales del ente que se acumulaban desde hace tiempo se desplieguen sin restricciones para llegar a lo que exigen en su conjunto" (Heidegger, 2000b, p. 387). Por ello podría decirse que con el acabamiento de la metafísica se abre de nuevo el horizonte de la ontología, del ser en cuanto ser. Pero, para ello, tenemos que aprender a pensar; es más: “Tenemos que aprender a 'leer'” (Heidegger, 2000a: 424), a leer el ser en el ente, porque esa es toda nuestra posibilidad. Así que aún no callamos.

Volvamos a la pregunta: ¿qué quiere decir ente, que es y ser? (Heidegger, 2000b, p. 429). ¿Cómo verdadea el ser? En Nietzsche la verdad pertenece a la esencia de la vida. Verdad, vida, estimación, valor van a una:

La verdad es la esencia de lo verdadero; lo verdadero es el ente; ente quiere decir lo tomado como consistente y fijo. La esencia de lo verdadero radica originariamente en un tomar-como-fijo-y-seguro de este tipo; ese tomar-como no es, sin embargo, una acción arbitraria, sino el comportamiento necesario para asegurar la existencia consistente de la vida misma. La verdad es, en esencia, una estimación de valor. (Heidegger, 2000b, p. 439)

Entonces, la verdad, en cuanto valor, es necesariamente una condición de la vida: la vida misma solo puede darse como tal, en su esencia, en cuanto se nutre del fundamento de la verdad, y por ello van a una, se codeterminan, la una precisa de la otra para poder darse. Aunque haya - aparentemente- contradicciones (contrariedades reales). Si verdadea la verdad, ella misma se rige por su "forma de ser"; lo que se quiere decir es que las contradicciones lógicas, por ejemplo, que quitan el 
fundamento de verdad a los silogismos racionales, en cuanto contradicciones "reales" (contrariedades), también son verdaderas porque no "falsean" la vida; es más, la vida misma las sustenta. El principio de no contradicción se da en un contexto eminentemente lógico (en el que se debería sostener); pero en la vida pueden darse y verdadear las contradicciones:

Aquel pensador que junto con Nietzsche ha llevado a cabo el acabamiento de la metafísica, es decir Hegel, ¿no ha superado acaso en su metafísica la validez del principio de no contradicción? ¿No enseña Hegel que la contradicción pertenece a la esencia más íntima del ser? ¿No es también esa la doctrina esencial de Heráclito? Pero para Hegel y para Heráclito, la "contradicción” es el "elemento" del "ser", por lo que trastocamos ya todo si hablamos de una contradicción del decir y del hablar en lugar de una contrariedad (Widerwendigkeit) del ser. (Heidegger, 2000b, pp. 479-480)

Con esto se comprende mejor la sentencia n. ${ }^{\circ} 493$ de La voluntad de poder, en la que Nietzsche declara que la verdad es aquella especie de error sin el cual ciertos seres no podemos vivir. Error como algo aparente, o sea, que aparece de una determinada manera en el devenir del mundo. No existe un mundo verdadero en el sentido de un mundo que ya es, que permanece infinita y finitamente así, eternamente válido. Pensar el mundo en tales términos desemboca en la nada, dice Heidegger. La apariencia del mundo, su representación tal cual aparece en algún instante es a lo que se llama arte. De ahí la gran importancia del arte en la configuración de la verdad. Y por ello la necesidad de transfigurar el sentido de verdad. Solo dentro de este renovado horizonte de la verdad se posibilita un "nuevo" orden del saber, aunque con él convivan las posturas metafísicas tradicionales (Heidegger, 2000c, pp. 163-166).

Aunque la metafísica se mantenga, de todas maneras la ontología emerge con su propia impronta. Diferenciándolo del ente, el ser vuelve a ser objeto del preguntar filosófico. El ser humano se pregunta por el ser, y se pregunta, también, si dicho preguntar le es esencial; es decir, 
si la esencia del ser humano pasa por la pregunta por el ser. Nos las habremos con los entes, nos referimos a los entes, preguntamos y respondemos por su sentido: vivimos entre entes pues los tenemos "a la mano”. “¿Pero 'el ser’?” (Heidegger, 2000c, p. 169). Heidegger se pregunta si será casual que nos cuestionemos por el ser, y que en el trato cotidiano con el ente olvidemos a aquel. ¿Hasta dónde podemos pensar el ser?, ¿no podremos desligarnos de su "sujeto" óntico (del ente que lo sostiene, que lo sujeta)?, ¿y cómo dar con su esencia sin tener clara de antemano la diferencia ontológica (entre ser y ente, es decir: entre ser y cosa, entre ser y realidad)?

\begin{abstract}
"Ontología" se ha convertido hoy otra vez en un nombre de moda; pero su tiempo ya parece haber pasado de nuevo. Por ello, es lícito recordar su uso más simple, vuelto hacia el significado de las palabras griegas; ontología: el interpelar y comprender el ser del ente. Con este nombre no designamos una disciplina especial de la metafísica, ni tampoco una "corriente" del pensamiento filosófico. Tomamos este título con tal amplitud que indica simplemente un acaecimiento, el acaecimiento de que el ente es interpelado en cuanto tal, es decir, en su ser. (Heidegger, 2000c, p. 170)
\end{abstract}

Sin la distinción entre ser y ente no es posible la ontología, y solo sobre esta base habrá de encausarse de manera adecuada toda metafísica. Ya no puede mantenerse de forma ingenua estudio alguno sin partir de tan fundamental distinción. Y por fundamental, básica, como otrora era básica la distinción entre "universal” y "particular" (Heidegger, 2000c, pp. 171-173). Hoy en día no se puede pasar por alto la diferencia ontológica: "A la distinción de ser y ente no podemos sustraernos, ni siquiera cuando presuntamente renunciamos a pensar metafísicamente" (Heidegger, 2000c, p. 195).

En Nietzsche, la metafísica no es la visión y juicio del ser humano, como se observó, es voluntad de poder, nihilismo, eterno retorno. En cuanto voluntad de poder es ser del ente como tal, es decir: la esencia del ente; en cuanto nihilismo es historia de la verdad del ente así determinado; en cuanto eterno retorno de lo mismo es existencia del ente 
en su totalidad. Dicha totalidad exige un "superhombre" adecuado a ese ser, que a su vez demanda una "justicia" acorde con la voluntad de poder que aparece siendo desde el pensar esencial (Heidegger, 2000c, p. 211). A fin de cuentas, la voluntad de poder es la esencia más íntima del ser, según el mismo Nietzsche explicita en La voluntad de poder, n. $^{\circ} 693$ (686).

La metafísica nietzscheana también es transvaloración de todos los valores estimados según el valor de la vida: "vida” es para Nietzsche otra palabra para decir ser. "El 'ser' no tenemos de él otra representación más que 'vivir'” (Heidegger, 2000c, p. 215). Heidegger señala que ninguna de estas expresiones tiene primacía en la metafísica de Nietzsche, al fin y al cabo la verdad en su esencia más íntima es devenir y, en consecuencia, no se da una fijación particular de ninguna de estas posibilidades ontológicas (Heidegger, 2000c, pp. 264-265), a la que se añade también la de teología. La voluntad de poder en cuanto eterno retorno de lo mismo se dirigen a una teología negativa que, según Heidegger, se muestra en la frase: "Dios ha muerto". "Esta no es la frase del ateísmo, sino la frase de la onto-teología de aquella metafísica en la que llega a su acabamiento el nihilismo propio" (Heidegger, 2000c, p. 283). Y, así, deviene, otra vez y de nuevo, aquel preguntar que enuncia un interrogante fundamental, y que en términos de Heidegger resonó así: pero ¿el ser?

\section{Heidegger}

¿Cómo se ha comprendido y se comprende el problema del ser?, fue la pregunta expuesta al inicio de este capítulo. Y de inmediato se apuntaba que quién mejor que Heidegger para responder semejante interrogante, porque el problema del ser y toda la ontología de nuestra época ha sido reelaborada con detalle y rigurosidad por este pensador. Algo de ello ya se vio en las anteriores páginas; sin embargo, Heidegger no fue solo un historiador de las ideas filosóficas, él se esforzó en pensar el ser. ¿En qué términos? Igual que hasta ahora, dejemos que el mismo Heidegger nos guíe. Sus obras son numerosas, así que es necesario ir con calma; no se abarcará la totalidad de su producción filosófica, 
pero sí lo necesario para escucharlo de manera adecuada. Continuemos, pues, a la escucha de este pensador.

La primera obra, que produjo un gran impacto, no solo en la filosofía europea, sino en Oriente y América Latina, fue Ser y tiempo (Sein und Zeit, 1963). Este libro inicia con un párrafo preintroductorio que señala el asunto a desarrollar. Lo primero que el lector encuentra es una cita en griego tomada de El sofista, de Platón, en la cual se manifiesta que antes se estaba familiarizado con la expresión ser pero que ahora hay perplejidad por no comprenderla.

Heidegger, entonces, pregunta si en la actualidad hay una respuesta a la pregunta que interroga por el ente, a lo que responde de forma negativa, por lo que se hace necesario plantear de nuevo la pregunta por el sentido del ser. Vuelve así a preguntar, que si nos encontramos perplejos; es decir, como hace veinticuatro siglos estaba Platón; e igual que antes la respuesta es negativa. Luego sentencia: la elaboración de dicha pregunta, aquella que interroga por el sentido del ser, es el propósito de Ser y tiempo (1963, p. 1). Vale la pena insistir en este detalle: el objeto de la investigación en Ser y tiempo no es el Dasein sino el ser: la pregunta que interroga por el ser. Solo en la primera parte de este tratado se interpretaría el Dasein como aquel ser con la capacidad de preguntar por el ser; sin embargo, vendría una segunda parte en la que se destruiría la historia de la ontología (quizá para posibilitar un nuevo comienzo de la misma, bajo otro horizonte de comprensión).

Heidegger jamás publicó aquella anunciada segunda parte, es más, de las tres secciones que componían la primera parte nada más se cuenta con dos. Con la edición de la Gesamtausgabe (la obra completa) de Heidegger, se conoció un valioso documento que él mismo señaló como la continuación de Ser y tiempo, aunque con su lectura se evidencia que es apenas un avance de la tercera sección de la primera parte y que no se puede tomar como la segunda parte del clásico de 1927. De todas maneras, queda claro que lo publicado en Ser y tiempo es la llamada "analítica existenciaria" del Dasein, pero que no constituye un estudio sobre el problema del ser en cuanto tal, razón por la cual no nos detendremos en ella, a lo que se suma lo que a continuación se evidencia. 
Dos años después de publicado Ser y tiempo, Heidegger presenta su conferencia inaugural en la Universidad de Friburgo: ¿Qué es metafísica? (1979). Inicia expresando que cada ciencia se ocupa de una región del ente, y nada más (actitud propia de la sumisión de la ciencia al ente, según afirma). Y llama de inmediato la atención de esta referencia al ente y a nada más, preguntando, entonces, ¿qué pasa con la nada? Toda respuesta buscada, en términos de "la nada es..." se convierte, ahí mismo, en un contrasentido: "nada", "es”, o ¿̇mejor habría que decir "la nada no es nada"? Y se pregunta Heidegger, ¿la nada es una especie de lo negado o hay negación tal vez porque hay nada? Hay, en el ser humano, un temple de ánimo que patentiza la nada: la angustia.

"La nada se descubre en la angustia, pero no como ente" (Heidegger, 1979 , p. 48). Y nos ocupamos tanto con los entes, que ignoramos la nada, al final como que no nos interesa. Pero el no y la negación siempre se hacen presentes en la vida cotidiana, ¿de qué manera? Pues, "el no, solamente puede hacerse patente sacando de su latencia lo que le da origen: el anonadar de la nada y, con él, la nada misma" (Heidegger, 1979 , p. 51). La nada es lo que origina la negación, y la negación se hace patente: atraviesa la existencia del ser humano, es algo lógico, pero también la nada y la negación son existenciales. Y van a una con el ser, dice Heidegger, ambos son, en esencia, metafísicos:

Pero si, por fin, nos hacemos problema de la nada, no solo resulta que esta contraposición queda mejor precisada, sino que entonces es cuando se plantea la auténtica cuestión metafísica del ser del ente. La nada no es ya este vago e impreciso enfrente del ente, sino que se nos descubre como perteneciendo al ser mismo del ente. (Heidegger, 1979, p. 54)

Por la nada se (nos) extraña el ente, con dicha extrañeza se causa admiración, de la admiración surge el preguntar, desde donde se busca la fundamentación, y así se constituyen los investigadores, dice Heidegger, quien finaliza su conferencia con la clásica pregunta de: ¿por qué hay ente y no más bien nada? 
Con esta misma pregunta, en 1935, Heidegger inicia su curso Introducción a la metafísica, donde parte de los mismos presupuestos: la filosofía no le debe nada a la ciencia ni depende de ella, es más cercana a la poesía, aunque tampoco se identifican. El espíritu de la filosofía y de la poesía son superiores al de la ciencia (Heidegger, 2003, pp. 32-33). Porque hay ente y no más bien nada, el pensador llega a hacerse una pregunta previa: ¿qué pasa con el ser? Para iniciar, ser es una palabra como nada, parecen términos vacíos, señalados a veces como mero vapor y error (por ejemplo, por Nietzsche); sin embargo, cabe cuestionarse si esa apariencia de error o vapor se le asigna al ser por su esencia en cuanto tal o, de pronto, se debe tal vez a que estamos demasiado llenos de ente. ¿No se debe tal vez a que nos hemos desviado de la senda del ser y ahora no encontramos retorno?, pues "es por esta y por ninguna otra razón que la palabra 'ser' no coincide con nada" (Heidegger, 2003, p. 44) y se disuelve como una nube ante los rayos del sol.

“QQué pasa con el ser?” es una cuestión que exige el ejercicio de una ontología renovada, en la cual se haga un sincero "esfuerzo de llevar el ser a la palabra, y concretamente mediante el recorrido por la pregunta ¿qué es del ser? (no solo del ente como tal)" (Heidegger, 2003, p. 45). Para Heidegger, la pregunta por el ser es una pregunta en esencia histórica, que se enraíza, según él, en el destino espiritual de Occidente o, aún mejor, en la historia universal de toda la Tierra, encarnada en la existencia del ser humano:

Nuestro preguntar la pregunta metafísica fundamental es histórico porque inaugura el acontecer de la ex-sistencia del hombre en sus referencias esenciales, es decir, sus referencias con el ente como tal en su totalidad, abriendo así posibilidades no planteadas y futuros, con lo que al mismo tiempo vuelve a vincular la ex-sistencia del hombre en su origen pretérito, endureciendo y dificultándolo de este modo en el presente. (Heidegger, 2003, p. 48)

La existencia total del ser humano, su constitución, la manera en que se está (en el mundo), y hasta la disposición anímica se proyectan desde 
el sentido del ser, por ello también la pregunta por el ser se entrelaza con el problema del lenguaje (Heidegger, 2003, p. 54). Una mirada a la etimología de ser muestra que, entre los griegos, esta palabra se refería a 'estabilidad' en dos sentidos: primero, en el sentido de phýsis, es decir, lo que está surgiendo; segundo, en el sentido de estable, lo permanente, lo que perdura, ousía (Heidegger, 2003, p. 65). El ser: lo que se manifiesta desde su estabilidad. Como verbo, en infinitivo, no da idea de una sustancia, y por eso más bien da la idea de vapor que se esfuma; pero sustantivado, anteponiendo un artículo, "el ser", da la idea de algo más estable que, de todas formas, está manifestándose, y así se le comprende como (lo que) es (Heidegger, 2003, p. 69).

Cuando uno dice "yo soy" de lo que habla es de "mi ser" y, aun así, todo lo demás es en cierta lejanía que se va abriendo, cuando estamos cerca de otro: nada tan extraño como el "tú eres" (Heidegger, 2003, p. 70). Y, aunque no aclara nada, en este contexto Heidegger expresa que en la actualidad "lo que vale es el nosotros. Ahora estamos en la 'época del nosotros' y no en la época del yo. Nosotros somos” (Heidegger, 2003, p. 70).

En sánscrito se dice: asus, que significa 'vida, lo viviente, lo autó-

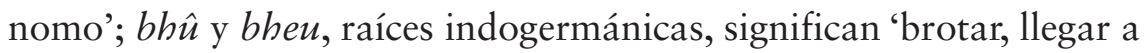
sostenerse por sí mismo', comprendido también como 'naturaleza, crecer'. En alemán, wes da la idea de morar, de habitar, permanecer en un lugar, el durar de algo presente. ¿Cómo emergió, entonces, el sentido de ser y se estableció con los significados que comprendemos hoy en día?, ¿qué pasa con el ser? (Heidegger, 2003, pp. 72-73).

$\mathrm{Al}$ ser lo comprendemos de antemano, en lo cotidiano; está "determinado" en el hecho de habérnoslas con el mundo y, sin embargo, al preguntarnos por su esencia ella queda por completo "indeterminada”. Sabemos lo que es (y lo que no es) en nuestro trato con los entes y lo encontramos en todos ellos, y de esta manera se nos presenta el ser como lo más inconfundible que existe. Aunque su comprensión parezca vacía, nada se le puede comparar, puesto que lo único que hay "otro" allende al ser es la nada, así que el ser no puede estar vacío. Aunque ser mantenga como referencia algo menos que una niebla vacía, sabemos que ser se distingue de no-ser y, en consecuencia, hay una gran riqueza en este concepto. 
Se comprende, entonces, la palabra ser, aunque dicha comprensión quede algo así como indeterminada y no se fije. Esto es lo que lleva a que el ser sea lo más digno de ser preguntado (Heidegger, 2003, pp. 74-81). $\mathrm{Y}$ a quien se le pregunta es al único ente con la posibilidad de preguntar, de comprender, quien se juega el sentido de su existencia, con lo que se borra todo vacío del ser, a tal punto, que ni siquiera lo gramatical y etimológico es suficiente para comprenderlo (Heidegger, 2003, p. 84). El ser está determinado por la existencia histórica que acontece desde antes, no es algo puramente abstracto (Heidegger, 2003, p. 89).

En la delimitación del ser, Heidegger lo "contrapone", primero, con el devenir, y concluye identificándolos: ser y devenir; luego, también lo "contrapone" a la apariencia. Sin embargo, debido a que ser es justo lo que aparece, lo que se muestra (en el ente), también se identifican: ser y apariencia. En cuanto que lo único que se piensa es el ser, lo que $e s, \mathrm{y}$ en cuanto que el ser se manifiesta en el pensar, también se identifican ser y pensar; $y$, por último, de igual manera Heidegger encuentra identidad entre ser y deber-ser (2003, pp. 90-180).

El ser permanece y deviene, o permanece deviniendo; el ser se mantiene (en sí, en cuanto tal) y ofrece (una) apariencia, es-aparentando (su ser) o aparece siendo. El ser es fundamento del ente que se equipara en el pensar: se piensa lo que es; el ser se da solo desde lo que debe ser, desde su esencia y sus posibilidades, no podría ser de otra forma. La delimitación del ser "sigue sosteniendo y dominando hasta hoy todas nuestras referencias al ser del ente en su totalidad, al devenir, a la apariencia, al pensar y al deber ser" (Heidegger, 2003, p. 182).

Pero devenir, pensar, deber ser, no son cosas vacías, sino que tienen su referente en la existencia misma del ser humano histórico que vive en su cotidianidad. Por esto "la pregunta ¿qué pasa con el ser? se revela al mismo tiempo como esta otra: ¿qué pasa con nuestra ex-sistencia en la historia?" (Heidegger, 2003, p. 182), además de ser la razón por la cual "hay que experimentar el ser nuevamente desde el fondo y en todo el alcance de su esencia” (Heidegger, 2003, pp. 183-184), desde las raíces de nuestra existencia histórica. Para lograrlo es necesario saber preguntar, y este preguntar ontológico, de seguro, "significa ser capaz de esperar, aunque fuese toda una vida" (Heidegger, 2003, pp. 185-186). 
Por la misma época, entre los años 1935 y 1936, Heidegger redacta "El origen de la obra de arte" (2001b) que publicará, luego, en Caminos de bosque. No es casual encontrar la perfecta continuidad con la obra que se acaba de comentar, porque saber preguntar quiere decir, también, saber a quién se le pregunta, y a estas alturas Heidegger le pregunta a la obra de arte. ¿Por qué? En primera instancia porque la obra de arte levanta un mundo, crea uno, es decir, crea la Tierra. Crear como traer aquí. La obra de arte lleva a la Tierra a lo abierto de un mundo; la Tierra: "Lo que hace emerger y da refugio" (Heidegger, 2001b, p. 33).

En la obra de arte, el escultor usa la piedra como el albañil, aunque no la desgasta; el pintor usa la pintura, y los colores avivan; el poeta usa la palabra, para dar un fundamento, no se queda en habladuría. La obra de arte se abre a la Tierra, creando el mundo perteneciente a un pueblo histórico, cuyo destino se forja en las decisiones simples y esenciales que toma ese pueblo (Heidegger, 2001b, p. 34-35). La obra de arte dice la verdad de la Tierra en ese mundo, el arte cuida la verdad en la obra: en la obra de arte acontece la verdad, y lo hace de modo poético. Todo arte es en esencia poema, dice Heidegger: "Es desde la esencia poética del arte, desde donde este procura un lugar abierto en medio de lo ente en cuya apertura todo es diferente a lo acostumbrado" (Heidegger, 2001b, p. 52).

Por el hecho de que es poema todo arte, se sigue que la arquitectura, la escultura, la música deben atribuirse a la poesía, un arte que emerge del lenguaje, él, que tiene la capacidad de nombrar al ente y su ser. Así, el poema, además de ser relato del desocultamiento del ente desde el ser, es, en su sentido esencial, todo lenguaje. La esencia del arte es poema, y la esencia del poema es mostrar (fundar) la verdad del ser desde lo ente, porque, de todas maneras, "la verdad es la verdad del ser" (Heidegger, 2001b, p. 58), y en cuanto el arte acontece como verdad, se puede ver en él que, más simplemente, acontece (Ereignis). La obra de arte, entonces, no hace más que evidenciar cómo la verdad acontece, creando un mundo desde la Tierra, donde el ser humano comprende el sentido del ser (Heidegger, 2001b, pp. 61-62).

Diez años después, Martin Heidegger escribió "La sentencia de Anaximandro" (2001c), también publicada en Caminos de bosque. 
Siendo esta, tal vez, la sentencia filosófica más antigua en la filosofía occidental, Heidegger se pregunta si todavía nos puede decir algo desde la distancia histórico-cronológica de más de dos milenios y medio. Nos trae la traducción que hace Nietzsche, y que se encuentra en el volumen x de las Obras completas: "De donde las cosas tienen su origen, hacia allí deben sucumbir también, según la necesidad; pues tienen que expiar y ser juzgadas por su injusticia, de acuerdo con el orden del tiempo" (citado por Heidegger, 2001c, p. 239).

Heidegger explica cómo, en dicha sentencia, cosas quiere decir todos los entes: las cosas objetos, propios de la naturaleza física, y también el ser humano con todo lo que el Dasein produce, incluida la palabra. Esta era la manera griega de comprender todo lo que es, manera que ha marcado a toda la cultura occidental, aquella que imprime un sello ontológico a la hora de asumir el mundo, a la hora de comprender el ente ante los ojos, a la hora de mirarnos a nosotros mismos y decir que somos. Sin embargo, desde aquel comienzo hasta nuestros días se nos ha ido olvidando el entre que hay en la diferencia de ser y ente: dicha diferencia ha conllevado, en efecto, al olvido del ser (Heidegger, 2001c, pp. 251-271). Y como la simplicidad del ser ha quedado sepultada en el olvido, ahora la mejor opción será hablar de manera poética de la esencia del ser, que no es otra que la tarea fundamental del pensar (Heidegger, 2001c, p. 277).

Seguramente se tendrá una mejor "aprehensión" del ser en su simplicidad si nos damos a la tarea más inocente, según Hölderlin, del pensar poético (Heidegger, 1968, p. 19), porque son los poetas los que "echan los fundamentos de lo permanente", según finaliza el poema "En memoria” de este poeta alemán. "Poesía es, pues, fundación del ser por la palabra de la boca" (Heidegger, 1968, p. 28) y, de manera poética es como el ser humano hace de esta Tierra su morada.

¿La tarea más inocente que busca aprehender lo más simple, el ser? Hasta ahora le ha correspondido a la filosofía interrogar lo más digno de ser preguntado, aquello simple: "Le damos el nombre de lo simple a aquella inaparentemente más difícil, aquello que cuando es, aparece a cualquiera inmediatamente y para siempre como lo más sencillo y más aprehensible” (Heidegger, 2008b, p. 15). El ser es lo más simple solo en cuanto es lo más aprehensible: el ente. En el ente el ser se 
muestra con toda sencillez, pero no hay que olvidar el entre que abre una distancia, una diferencia, entre ente y ser, la diferencia ontológica.

En cuanto simple, el ser no es lo más sencillo, sino algo bastante complejo, y por ello se hace necesario volver a interrogar: ¿qué pasa con el ser? Es una pregunta compleja, excepto para aquel a quien le urge tener una respuesta inmediata (Heidegger, 2008b, p. 23). Si la tarea de la filosofía radica en el preguntar, siempre hay que volver a la pregunta. Heidegger critica que los griegos no se hayan preguntado de forma esencial por el estado de desocultamiento del ente, como si para ellos aquel estado fundamental del ser no hubiera sido lo más digno de ser preguntado. Los griegos "establecieron y fundaron este fundamento, pero no siguieron preguntando de manera expresa por el mismo" (Heidegger, 2008b, p. 106), y quizá por ello — podría decirse- se fue dando el olvido del ser.

Es tiempo de volver a preguntar: cuestionarnos cómo fue aquel inicio griego y asumir cómo habremos de hacerlo ahora para alcanzar la comprensión del sentido del ser; "solamente encontraremos el camino hacia allá mediante una meditación sobre el inicio y sobre aquello que le fue asignado" (Heidegger, 2008b, p. 117), lo que podrá posibilitar un nuevo inicio para la ontología. Pero esto no puede tratarse, en manera alguna, "de una doctrina sistemática de la verdad" (Heidegger, 2008 b, p. 134) del ser, ya no es época de los sistemas. Recuérdese que es de forma poética como habita el ser humano su morada y que, por consiguiente, es de forma poética como se desoculta el ser.

No deberíamos permitirnos que siga dominando el olvido del ser, no deberíamos mantenernos en tal indiferencia con el ser, ni disculparnos ofreciendo señalamientos desde la metafísica y la ontología de tal manera que nos mantengamos en lo que hay, "en lugar de construir hacia el futuro, aun sin verlo” (Heidegger, 2008b, p. 171). Que el pensar poético no es filosofía es un parecer que se mantiene dentro de los límites de una tradición de filosofía sistemática que sigue soñando en tratados de meta-física. No saber cómo saber de otra manera se hace necesario.

Heidegger vuelve a recordar que "no toda palabra que contenga una negación es algo negativo en el sentido de desprecio" (Heidegger, 2008b, p. 141); no todo lo negativo es algo carente, ni lamentable, ni displicente... si así lo creemos se debe a que sabemos muy poco de 
lo negativo, y porque ya nuestro entendimiento se ha rebajado a ser calculador. Para esta clase de entendimiento "nunca entra que un 'no' pueda provenir de un exceso de abundancia y ser la donación más elevada, y que este 'no' pueda superar infinitamente, es decir, esencialmente, todo sí ordinario" (Heidegger, 2008b, p. 142). El saber negativo puede ser muy positivo, nos dice Heidegger, y captar lo originario en esencia. Y ¿por qué no?

Habiendo llegado a este punto, o mejor, a este nivel del pensar heideggeriano, se comprenderá de forma adecuada la manera como se nos ofrecen los textos de los que nos ocuparemos ahora: Aportes a la filosofía (2006c), Meditación (2006d), La historia del ser (2011) y Sobre el comienzo (2007f). Son textos cuya presentación formal no tiene que ver con tratados sistemáticos, parecieran, más bien, colecciones de aforismos bastante profundos y algo extensos, que en algunas ocasiones se repiten una y otra vez, refiriendo algún detalle de una u otra manera, recurriendo inclusive a la poesía, al decir poético. No podría ser para menos, si se busca ser consecuente con la experiencia existencial que está viviendo su autor, y que se ha ido percibiendo en esta aproximación al pensamiento ontológico de Heidegger. De todas maneras, acá se continuará con el ejercicio de buscar ese aporte del pensador al develamiento del ser más allá (o más acá) del ente.

Sus Aportes a la filosofía. Acerca del evento fueron escritos de 1936 a 1938, publicados en 1989, y traducidos a la lengua castellana por Dina Picotti apenas en 2006. La crítica los considera la segunda gran obra de Heidegger después de Ser y tiempo, pues lo que allí se busca es proponer los lineamientos generales del nuevo inicio con que ha de comenzar de nuevo la aproximación al ser en cuanto tal, por medio de una práctica del pensar (ontológico), la cual cobró para el autor más consistencia que la tradicional filosofía metafísica, en la que se ha olvidado seguir preguntando lo más digno de ser pensado: el ser.

Hay que dar, pues, el salto "de la metafísica al pensar según la historia del ser"12" (Heidegger, 2006c, p. 21), que se hace por medio de la

12 A esta época pertenece la grafía de ser no como Sein sino como Seyn, un modismo arcaico del alemán, y que algunos editores y traductores a la lengua castellana decidieron escribir con ' $\mathrm{S}$ ' mayúscula [Ser] para llamar la atención 
meditación: meditar el problema del ser desde él mismo y no desde el ente (Heidegger, 2006c, p. 24), preguntando por su esencia para mantenernos en el presente de este preguntar fundamental. La pregunta por el ser es, para Heidegger, la pregunta de todas las preguntas, que muy pocos han vuelto a realizar (2006c, p. 27). Esta meditación exige una actitud apropiada al nuevo inicio, no puede realizarse de la misma forma que en los primeros tiempos, cuando se hizo bajo el horizonte del asombro: ahora será bajo el horizonte del presentir (Er-ahnen) (Heidegger, 2006c, p. 35).

Dina Picotti traduce Ereignis como evento. Así se comprende, en este nuevo inicio, al ser. Ya no apañado de manera estática como el ente, sino como algo dinámico que se ha ido constituyendo de forma histórica. El ser acaece, podría decirse. En cuanto evento resulta una negación del ente, lo que se evidencia como cierto conflicto: lo noedor del ser (Heidegger, 2006c, p. 40). Pero no es una negación destructiva del ente, ¡de manera alguna!, es más bien el cuidado por la verdad del ser (Heidegger, 2006c, p. 46), una verdad reposada que se manifiesta en la fuerza fundante, "reuniente" y retenedora del ser (Heidegger, 2006c, p. 61).

¿Cómo mostrar dicha fuerza, cómo señalarla o representarla? "Al pensar solo le queda el más simple decir de la más sencilla imagen en el más puro callar. El primer pensador venidero tiene que ser capaz de ello" (Heidegger, 2006c, p. 72). Y ¿entonces? Pero ¿acaso con este lenguaje que "comunica" apenas lo ente podría mostrar el ser? ¿Es posible un nuevo lenguaje para el ser? A no ser el silencio, la sigética, como "lógica” propia de la ontología, dice Heidegger. Algo sí es seguro: el camino apropiado es el preguntar (Heidegger, 2006c, p. 89). Se preguntará, por ejemplo, ¿por qué "el no" pertenece a la esencia del ser, o viceversa, el ser al no?, ¿qué es lo noedor del ser? (Heidegger, 2006c, p. 219), ¿cómo la vida es un modo de esenciar el ser? (Heidegger, 2006c, p. 226) o ¿qué papel desempeña en el ser el estar ahí y el estar ausente? (Heidegger, 2006c, pp. 245-264), y tantos otros interrogantes que van emergiendo del preguntar mismo acerca del ser.

sobre este detalle. Acá bastará esta nota de pie de página, porque de fondo lo que quiere radicalizar Heidegger es la pregunta por el ser en cuanto tal: el ser, que en castellano se dice de forma bastante diferente a ente. 
Aunque "la filosofía es el preguntar por el ser" (Heidegger, 2006c, p. 339), de fondo, y desde Anaximandro hasta Nietzsche, se ha reducido a preguntar por el ser del ente. Ahora se anuncia y se enuncia, mejor, como la pregunta por la verdad del ser:

La pregunta por el ser deviene ahora pregunta por la verdad del ser. La esencia de la verdad es ahora interrogada desde el esenciarse del ser, concibiéndola como el claro de lo que se oculta y con ello como perteneciente a la esencia del ser mismo. La pregunta por la verdad "del" ser se desoculta como la pregunta por el ser "de" la verdad [...]. Ahora el preguntar por el ser ya no piensa a partir del ente, sino que ha sido, como pensar del ser, forzado a través del ser mismo. (Heidegger, 2006c p. 342) ${ }^{13}$

Ahora habrá que esperar a ver quién se interesa por el ser (Heidegger, 2006c, p. 353) desde este nuevo horizonte de la verdad, que habrá de patentizar la historia del ser que se vivencia en la vida (Heidegger, 2006c, p. 357), de tal manera que ya no es decible como algo general y vacío (Heidegger, 2006c, p. 365): ser es Ereignis, evento, evento-apropiador, acontecimiento-ontológico, acaecimiento-de-la-verdad en la que somos. Con ello se radicaliza la diferencia con el ente: "El pleno esenciarse del ser en la verdad del evento hace reconocer que el ser y solo el ser es y que el ente no es" (Heidegger, 2006c, p. 374). En el primer inicio, la metafísica, desde Platón, convertía al ser en ente “porque pone al ser como 'idea' por meta del ente y de este planteo de meta posteriormente suspende entonces en cierto modo a la 'cultura'" (Heidegger, 2006c, p. 377).

13 He retirado todos los paréntesis en los que la traductora inserta los términos alemanes de ciertas palabras, para facilitar la fluidez de esta cita que resulta trascendental en el pensamiento de Heidegger: el proyecto del ser ya no pasa por interrogar al ente (como siempre lo había sostenido, según el horizonte propio de la metafísica), ahora, en este nuevo inicio, se debe interrogar a la verdad, a la verdad del ser mismo. 
Estas reflexiones del Ereignis continúan y se amplían en la Meditación, escrita entre 1938 y 1939. En principio, no se encuentra nada nuevo en este texto, tal vez porque responde de forma literal a su título. Meditar una y otra vez el asunto del ser como evento que acaece históricamente, para confirmar que se toma distancia de la metafísica en la que se trata del ente en su totalidad y con el fin de tener el ánimo de avanzar hacia otro inicio del pensar. Como es natural, este texto, como el anterior, se presenta como en extensos aforismos, que guardan entre sí una relación, podría decirse que "ontológica”, en cuanto los une la pregunta por el ser, precedidos por una introducción compuesta por siete breves poemas.

En el apartado sobre la filosofía define la poesía como el saber esencial que busca la esencia de la verdad, y que por ello mismo busca el paso a la poesía para poder decir el ser (Heidegger, 2006d, p. 57). "La filosofía es del ser", dice Heidegger, en cuanto este se esencia en su verdad. No trata del ente, ya que "lo otro del ser no es ni siquiera el ente; el ser no tiene ningún otro ante sí, pues la misma nada es totalmente de la esencia del ser" (Heidegger, 2006d, p. 61). De esto habla el nuevo horizonte de comprensión del problema del ser en el nuevo inicio del pensar, que de todas maneras será un hablar calmado, que surge del seno mismo de la meditación cuando se pregunta por el ser. Esta es "la única pasión del pensar" (Heidegger, 2006d, p. 68): meditar el ser preguntando por su esencia a la verdad y no al ente, en donde una de las posibilidades es "pensar" al ser como devenir, y en el devenir plantear al verdadero ser como la vida (Heidegger, 2006d, p. 78).

En el cuarto apartado, sobre el proyecto del ser, sentencia Heidegger: "El ser — nada divino, nada humano, nada mundano, nada terrenaly sin embargo a todo en uno el entretanto -inexplicable, ineficaz, fuera de poder e impotencia se esencia el ser [...]" (2006d, p. 81). Como se evidencia, no es un concepto de ser (por demás, a este nivel, ya no son necesarios los “conceptos"), pero sí es el contexto desde el cual se puede comprender la apuesta de Heidegger por este nuevo inicio de aproximación al problema del ser. También sugiere que en los inicios de la metafísica el ser se ocultó en el surgimiento propio de la phýsis (y por ello su asimilación como ente), al final de esta época (propia del 
primer inicio) el ser se entendió como "vida" (hegemonía buscada por la voluntad de poder), y ahora, en el nuevo inicio de esta época, apenas comenzando, el ser se vislumbra como Ereignis (evento-apropiador) de la verdad (Heidegger, 2006d, p. 84). De todas maneras, como él lo señala: "Lo que sin embargo 'significa' este otro comienzo de la historia del ser no lo sabe nadie" (2006d, p. 63).

La sentencia "el ser es, el ente no es", podría matizarse como el ente es, el ser se esencia, pero esta forma está hablando desde la tradición metafísica (Heidegger, 2006d, p. 88), en particular porque señala que "el ente es". Que el ser se esencia es un decir que aunque a primera vista no dice mucho, señala la indigencia del nuevo inicio y, en el fondo, de la esencia misma del ser: no como carencia, y menos como carencia de ente, sino como abismo, profundidad, como dejarse en el ser para que él diga desde sí mismo (Heidegger, 2006d, p. 93).

De aquí en adelante, Heidegger presenta varios apartados, ya sobre la verdad, ya sobre el ser, la historia, el olvido del ser, el pensar del ser y de nuevo sobre el ser, en los que ratifica una y otra vez lo hasta acá expuesto. En el orden de esta investigación, tal vez baste señalar que al final del apartado sobre el devenir (2006d, pp. 239-245) vuelve a tratar sobre la vida haciendo alguna referencia a la cultura; también dedica el apartado xxiv al ser y la negación (2006d, pp. 251-255), donde esta no es proscrita sino, al contrario, es comprendida como esencial al ser.

Para finalizar esta meditación no se puede dejar pasar por alto que, para Heidegger, ya no es imperativo detenerse en la pregunta metafísica por el ser puesto que ella se inscribe dentro de una "ontología realista" del ente. De esta manera se congracia con las ciencias y aplica un método propio de las investigaciones de la realidad (Heidegger, 2006d, p. 292), mientras que la pregunta por el ser, bajo el horizonte de este nuevo inicio que devela la historia del ser, lo mostrará en su puro esenciarse desde la verdad, sin método alguno, pues no hay más que seguir su curso (el curso de la esencia del ser) en la historia, que él mismo se va abriendo (Heidegger, 2006d, pp. 293-295). En últimas, "la auténtica meditación sobre la pregunta por el ser" ya no es ni metafísica ni ontológica (Heidegger, 2006d, pp. 296 y 325).

¿Entonces? ¿No tenemos, ahora, derrotero alguno? “¡Pregunta al ser! Y en su calma, como el comienzo de la palabra, responde el 
dios" (Heidegger, 2006d, p. 300). Esta historia del ser, en su nuevo inicio, es un saber que "no consiste en acontecimientos y en el aparecer y desaparecer de opiniones sobre el ente sino es lo que responde la voz de la calma, asume esta voz en el callar de un decir propio" (Heidegger, 2006d, p. 304). Por demás, el pensar es mero preguntar, no responde nada, no contesta nunca (pp. 304-305), es saber (pp. 309 y 312).

Por la misma época, entre 1938 y 1940, Heidegger redacta, con el mismo estilo, La historia del ser (2011). Es un texto paralelo, en lo que respecta a su temática, a la Meditación, y donde, en el fondo, dice lo mismo. Eso sí, profundiza al señalar que el ser "no es hallable desde la inmanencia, ni vislumbrable a través de la trascendencia. Ambos caminos no conducen a la meta" del ser (2011, p. 77), sino solo del ente. El ser "no 'está' sobre nosotros, ni en nosotros, ni en torno nuestro, sino nosotros somos 'en' él como evento" (2011, p. 77). Sin embargo, en esta obra, aunque se dice lo mismo, ya no se hace de la misma forma. Comienzan a aparecer apartados en verso, pequeños poemas que hablan del ser. La nueva "ontología”, por decirlo así, la nueva forma de hablar el ser, tomando distancia de la metafísica y sus viejos tratados conceptuales que al final no dijeron nada (del ser), va adquiriendo también una nueva forma de expresión. "El pensar esencial es la poesía sin imagen en la palabra del dicho del ser" (Heidegger, 2011, p. 195).

Recuérdese que la introducción de la Meditación está conformada por siete poemas. Ahora veamos algunos de estos textos en su novedad. Para preguntar la relación del ser con el “somos”, Heidegger (2011) expresa:

¿Quiénes somos?

¿Y somos entonces?

¿Qué significa "ser"? [...]

¿Quién decide sobre el "ser”?

¿O decide el ser sobre cada quien y cada preguntar? ¿Y de qué manera? ¿Qué es el ser? ¿Cómo ha de desocultarse y ser llevado a su verdad? ¿Qué es verdad?

Estamos en lo extremo de estas preguntas. (p. 25) 
¿Qué significa “ser"?, ¿qué es el ser? Es la pregunta por el sentido del ser la que tuvo en vilo a Heidegger. Toda su filosofía no hace más que pensar en este asunto, siempre. La mirada de este filósofo alemán se concentra en dicha cuestión y, cuando se aproxima a la historia de la filosofía, este preguntar es su horizonte de comprensión, no hay otro. Al final se da cuenta de que es necesario otro inicio para pensar el ser. Y para referirse al nuevo inicio, al curso en que se da el saber del ser, al producirse el salto que debe darse para una nueva comprensión del ser, Heidegger (2011) prevé un posible camino:

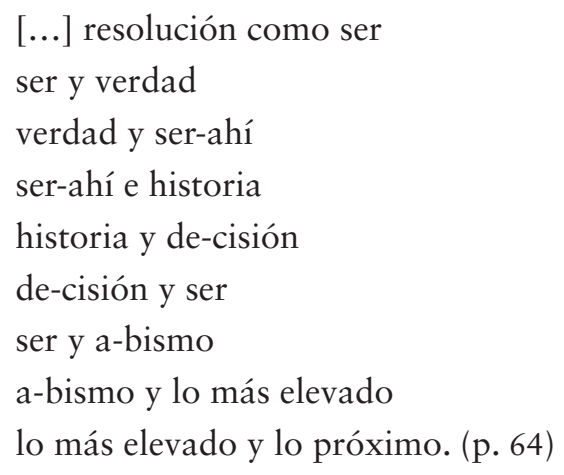

$\mathrm{Al}$ volver a interrogarse por el sentido del ser en cuanto tal, no como el ser del ente de la metafísica, sino el ser en el horizonte del nuevo inicio que se esencia en la verdad, ofrece algunas "percepciones" y finaliza cuestionándose:

El ser

no es un "viviente" ("algo vital”),

no es algo "espiritual”,

no es algo "material",

no es algo "inmaterial”.

Pues aquí por doquier se ha tomado referencia a un "ente",

[a partir del cual el ser es explicado e interpretado.

Tiene que hacerse el simple paso: que el ser no es un ente.

El ser es ser (des-ocultación - evento).

Pero ¿cómo saber esto, es decir, el puro esenciarse? (p. 161) 
Percepciones que se diluyen. Caminos que se esfuman. En definitiva, tarea por hacerse. Y, por último, quedarse en la pregunta de lo que se ha empezado a responder. ¿Habrá, acaso, respuesta? Con el mismo título, unas páginas más adelante nos ofrece otro poema:

Lo más vacío y la riqueza.

Lo más general y lo único.

Lo más inteligible y la ocultación.

Lo más empleado y lo que brota.

Lo más confiable y el a-bismo.

Lo más olvidado y el re-cuerdo (re-cordante).

Lo más dicho y el silenciamiento.

Lo más discrecional y lo indispensable.

El epí-logo y nombre para el "es" del enunciado y el pró-logo y

[verbo para el fundamento del silencio. (pp. 169-170)

Todo cabe en él, y nada se comprende sin él, pero la claridad se disipa. $\mathrm{Al}$ fin no queda más que el silencio. En efecto, a veces el silencio lo debe embargar, para no decir casi nada; son suficientes tres versos para hablar del Ereignis como nueva manera de comprender el ser: "El evento como el ser. / El ser como la verdad. / Solo el ser es” (Heidegger, 2011, p. 172).

Al fin y al cabo es lo único que hay que decir (¿porque tal vez sea lo único dicho?). Si el ser es, ¿qué más hay que decir? Al finalizar el pequeño poema "El ser es lo antiguo", los dos últimos versos sentencian: "El ser es. / Esto, el único dicho" (p. 173).

Respecto de la superación de la filosofía metafísica, los pensadores se preguntan por el (se exponen al) ser mientras los otros (los filósofos) se quedan con el ente. De forma implacable lo expresa Heidegger, aunque ello moleste a algunos académicos. El pensador tiene mucho trabajo al habérselas con el ser y esforzarse por tomar distancia de la mediación del ente, que lo ha llevado a su olvido. Los otros no alcanzan a despegarse del ente, de la cosa, de la realidad ahí ante los ojos o formalmente aprehendida. Sí, de manera implacable debe decirse: "El pensador permanece en el ente expuesto al ser. / Los otros 'abogan' por el ente en el ente" (Heidegger, 2011, p. 188). 
Entonces no le queda mucho qué decir. No hay tanto qué decir. Ya se ha observado la necesidad del silencio. Pareciera que emerge un abismo y que, en vez de aclararse, se oculta todo lo que es, el ser. Por eso uno de sus últimos versos en La historia del ser es este: "Verdad del ser es el claro del ocultarse" (p. 258).

No se olvide que Heidegger también se había dedicado al estudio de algunos poetas. Ofreció todo un curso semestral, en 1934 y1935 a la comprensión de dos himnos de Hölderlin: "Germania” y "El Rin", de cuya labor concluye: "La intimidad del saber poético-pensante confiere aquel conocimiento del ser, que queda lo suficientemente fuerte como para que el encuentro del dios sea un sitio" (Heidegger, 2010, p. 243), sea cual fuere este lugar.

Ganado, pues, este horizonte del poetizar ontológico, inicia la tarea del comienzo desde el que habrá que pensar el ser, y en el que habrá de mantenerse, como se verá, por ejemplo, en la obra de 1944: Las sendas del comienzo. Antes, en 1941, Sobre el comienzo inicia así: "Antiguos vienen / Por el ser asumidos / Ellos osan / El decir / De la verdad del ser: / Evento del comienzo / Para resolución en la despedida” (Heidegger, 2007f, p. 17).

Interpretaciones varias y múltiples devendrán de estos poemas heideggerianos. No se sabe aún qué tanto quería decir Heidegger. "Lo que el pensador y el poeta tienen respectivamente en el saber, nunca lo agota su palabra" (Heidegger, 2007f, p. 134). Lo que busca es apañar el nuevo inicio del pensar el ser, que según él es el comienzo del ser en la comprensión de los pensadores. Los filósofos se quedan en el ente; ahora es el tiempo de un nuevo comienzo que exige poetizar el pensamiento en busca de su máxima originalidad: "Solo los pensadores iniciales, pero no los 'filósofos' (metafísicos) se encuentran en referencia esencial, no obstante nunca homogénea, al poeta" (Heidegger, 2007f, p. 140). No se puede interpretar a la ligera a los poetas: "Cada vez cada poema es para interpretar en lo único, como un dicho de lo sagrado" (Heidegger, 2007f, p. 143), la plurivocidad exige un sabio cuidado: “¿De dónde surge la contenida plurivocidad? / Porque es dicho el ser. / Pero este es lo simple" (Heidegger, 2007f, p. 144).

¿Para qué decir y repetir, otra vez, lo mismo? Heidegger ya se ha pronunciado. Sus "sendas perdidas" han hallado un sendero que 
comienza él mismo a caminar. Hagamos una pausa mientras meditamos una de las últimas sentencias de Sobre el comienzo de Heidegger: "Tan solo tiene que haber de nuevo pensadores que simplemente piensen suficientemente” (2007f, p. 168). No se diga más. 